\title{
Regulation in a Liberal State: The Role of Non-Commodity Values
}

\author{
Richard B. Stewart $†$
}

This Article aims to clarify the background understandings that inform and structure regulatory and administrative law ${ }^{1}$-fields of law long criticized as undisciplined and unordered. A great appeal of the law and economics movement was its promise of a single jurisprudential framework sufficiently general and trenchant to provide a unifying order, here and elsewhere. That movement has provoked competing unitary theories. ${ }^{2}$ The inconclusive battle among these theories has reawakened skepticism as to the possibility of any successful unitary theory. The effort to structure law is now shifting to complex theories composed of several different conceptions of legal ordering. ${ }^{3}$ Such theories are symptomatic of what we might call a post law-and-economics era. They try to avoid procrustean distortions by responding to the law's richness and intricacy without lapsing into nominalism.

This Article is part of this emerging genre. Although not offering a fully developed theory, it argues that administrative and regulatory law reflect several competing background understandings of the ends of government: the protection of entitlements, the promotion of production, and the nurture of non-commodity values. It shows how these three conceptions are related to American liberal traditions of law and political theory,

$\dagger$ Byrne Professor of Administrative Law, Harvard University. Bruce Ackerman, Charles Fried, Frank Michelman, Steven Shavell, Cass Sunstein, and Stephen Thernstrom provided helpful comments on earlier drafts of this Article. This Article has also benefited from comments at faculty workshops at the University of Chicago and Harvard Law Schools.

1. This Article is concerned with "economic" regulation, which conventionally includes price, service, and entry regulation to control market power or economic rents, and those aspects of "social" regulation (including environmental protection, consumer protection, and health, safety and broadcast regulation) that seek to correct other "market failures" involving physical or economic spillovers. For an analysis of various forms of regulation, see S. BREYER, REGULATION AND ITS REFORM (1982).

2. See, e.g., C. FRIED, CONTRACT AS PROMISE (1981); Epstein, Defenses and Subsequent Pleas in a System of Strict Liability, 3 J. LEGaL STUD. 165 (1974); Epstein, A Theory of Strict Liability, 2 J. LEGAL STUD. 151 (1973). A different form of unitary theory, not directly responsive to the claims of the law and economics movement, is J. ELY, DEMOCRACY AND DISTRUST (1980). This phenomenon of grand unitary theories is analyzed in Unger, The Critical Legal Studies Movement, 96 HARV. L. REV. 561, 574-76 (1983).

3. See, e.g., J. Mashaw, Bureaucratic Justice (1983); L. TRIBE, AMERIGaN CONSTITUTIONAL LAW (1978); Clark, The Four Stages of Capitalism: Reflections on Investment Management Treatises, 94 Harv. L. REV. 561 (1981); Stewart \& Sunstein, Public Programs and Private Rights, 95 HARV. L. REV. 1195 (1982). Bruce Ackerman's Foreword to this symposium invites such scholarship. See Ackerman, Law in the Activist State, 92 YALE L.J. 1083, 1085 (1983). 
and to the problems in reconciling regulation with liberal principles. A principal aim of the Article is to develop the concept of non-commodity values and show that their nurture is, and should be, an important objective of regulatory and administrative law.

Liberalism has repeatedly been attacked as an impoverished creed that ignores the social context of human development. If conceptions of the good are individual, and if government is forbidden to endorse any single form of the good, then society seems reduced to a system in which each individual seeks to extract the largest feasible portion of available resources in order to promote his own private ends. A market economy is claimed to be the institutional archetype of such a conception of society. According to this critique of liberalism, the market economy stunts personal development by narrowing the terms of human association and fostering commodity consumption as a dominant value. Competition for material advantage also assertedly breeds egoism, undermining the infrastructure of mutual trust upon which society (including the market) ultimately depends. Thus capitalist liberalism was caricatured and attacked in the nineteenth century; ${ }^{4}$ thus it is today. ${ }^{5}$ This, like all caricatures, is overdrawn but has important elements of truth. The nurture of non-commodity values is the appropriate response.

Part I examines the general relationship between the liberal tradition and regulation. Part II discusses and rejects the minimalist liberal thesis that regulatory statutes should be interpreted as "deals" among competing private interests. Parts III and IV discuss two other conceptions of the proper role for regulation and administrative law in the liberal state-protection of entitlements and maximization of wealth-and discuss the limits of their explanatory and justificatory power. Parts $V$ and VI discuss the proper role of non-commodity values in regulatory and administrative law. The discussion throughout relies on examples from environmental and broadcast regulation.

Glarifying the concepts of entitlement, wealth-maximization, and noncommodity values will not by itself resolve hard choices or hard cases. But it will serve to focus and discipline thinking about the ends and means of administrative regulation not only on the part of scholars and judges but also of legislators, administrators, and others who have a hand in shaping regulatory law. These conceptions, which are firmly rooted in the liberal tradition, may appropriately be understood as the foundations of an ad-

4. See K. MARX, CAPITAL 163-77 (Fowkes trans. 1977) (1st ed. 1867) (discussing "The Fetishism of Commodities").

5. See, e.g., F. HIRSCH, SOCIAL LIMITS TO GROWTH 84-94 (1976); W. MCWILliAMS, THE IDEA OF FRATERNITY IN AMERICA 109-10 (1973). 
ministrative constitution-a charter of basic principles for regulatory and administrative law.

\section{Liberal Principles and Regulatory Law}

While it would be foolhardy to attempt to formulate a definitive creed, the argument which follows requires a prefatory sketch of liberal principles and their relation to problems of administrative justice. ${ }^{6}$ Accordingly, I first discuss the link between basic liberal principles and regulatory law. I then focus on the historical conditions of American liberalism ${ }^{7}$ and the implications flowing from the rise of centralized regulation.

\section{A. Neutrality and the Prohibition of Coerced Wealth Transfers}

Liberal theory affirms the equal right and opportunity of each individual to pursue her own conception of the good. ${ }^{8}$ Government aids this enterprise by securing individuals' private and political liberties, underwriting private agreements and associations, and providing other nurturing social services (such as education) and other collective goods (such as healthy environments). This view is not skeptical or agnostic about moral norms. Indeed, it insists upon respect for the moral value of citizens' rights and of liberal institutions, such as the rule of law, designed to protect those rights. Like every legal and political theory, it rests on potentially controversial value choices. Its premise is that the ultimate good for men and women is plural and can be realized only by voluntary efforts, both individual and concerted. Society is understood as a mutual enterprise in realizing many forms of excellence that no single individual can achieve. ${ }^{9}$ Accordingly, government must strive to remain neutral among competing conceptions of the good, while simultaneously securing the capacity of individuals and associations to realize their chosen ends. Applying this ideal to the far-reaching activities of modern regulatory government raises several dilemmas examined in this Article. ${ }^{10}$

6. For an earlier discussion of this subject, see Stewart, The Reformation of American Administrative Law, 88 HARV. L. REV. 1667, 1671-76 (1975).

7. For various accounts of American liberalism, see, e.g., L. HARTZ, THE LIBERAL TRADITION IN AMERICA (1955); S. HUNTINGTON, AMERIGAN POLITICS, THE PROMISE OF DishaRMONY (1981); $R$. Kelley, The Transatlantic Persuasion (1969).

8. We need not consider here whether the master premise of liberalism is neutrality, see B. ACKERMAN, SOCIAL JUSTICE IN THE LIBERAL STATE 10-12, 43-45, 327-48 (1980), or equal concern and respect, see Dworkin, What Liberalism Isn't, N.Y. REV. BOOKS, Jan. 20, 1983, at 47. How far these can be meaningfully separated is problematic. Liberal theory rests on the potentially paradoxical view that "freedom in the fullest sense implies both variety and equality." L. HARTZ, supra note 7, at 57.

9. See J. Rawls, A THEORY OF Justice 3-22 (1971); cf. J. Passmore, The PERFectability OF MAN 11-27 (1970) (surveying and rejecting theories which argue that goal of man is to achieve particular form of perfection); J. VINING, LEGAL IDENTITY 139-69 (1978) (recognition and integration by legal system of different personal roles and conceptions of the good).

10. Traditionally, liberal principles such as neutrality and the ban on private wealth transfers 
A liberal design for government can seek to minimize violations of liberal principles through two strategies. The "wholesale" strategy relies upon the general design of government to minimize the probability that measures will be adopted that violate liberal principles. The "retail" strategy requires review of individual measures on a case-by-case basis. Courts, of course, are but one of the institutional mechanisms through which such strategies might be implemented.

The implications of liberal theory for regulatory law have traditionally been divided into the procedural and the substantive. The procedural implications are encapsulated in the idea of the rule of law: The government's authority should be exercised in accordance with general rules publicly acknowledged in advance and impartially applied. ${ }^{11}$ The substantive implications flow from the principle of neutrality, which bars government from using its coercive powers in a partisan manner to advance some citizens' particular conception of the good. ${ }^{12} \mathrm{~A}$ corollary principle prohibits government from using its power simply to redistribute wealth from some citizens to others. Consider, for example, a regulatory system that limits entry to the interstate trucking industry, raises prices to consumers, and gives truckers monopoly profits. On what basis are truckers to be preferred to consumers? If the truckers' advantage reflects nothing but their success in manipulating governmental power to their own purposes,

have been understood as imposing negative limits on the range of regulatory undertakings by government. See R. KELLEY, supra note 7, at 242, 296-97, 324-25 (19th-century democratic aversion to government's promoting economic development reflected fear of corruption and special interest manipulation). In recent decades, however, the principle of equal concern and respect has been invoked as an affirmative ground for government action, in areas such as regulations aimed at eliminating race or gender discrimination in employment or housing. The theoretical and institutional implementation of the contrast between "negative" and "positive" conceptions of liberty is, of course, a staple problem of the liberal tradition. This Article may be understood as addressing certain aspects of this problem in the specific context of regulation.

11. See F. HAYEK, THE CONSTITUTION OF LIBERTY 148-61 (1960); Kennedy, Legal Formality, 2 J. LEGAL STUD. 351 (1973); Stewart, supra note 6, at 1698-1702.

12. This Article deals with regulatory measures aimed at redressing the adverse consequences of "economic" and social" spillovers and interdependencies. See supra note 1 . It accordingly does not address the political, theoretical, and legal problems associated with paternalistic measures that restrict an individual's conduct in order to protect that individual's rights or enhance his welfare. Paternalistic measures aimed at coercing allegiance or conformance to a particular conception of the good are inconsistent with liberal principles. See Note, Limiting the State's Police Power: Judicial Reaction to John Stuart Mill, 37 U. CHI. L. REV. 605 (1970); see also L. TRIBE, supra note 3, at 886-921, 938-41, 974-80 (discussing rights of privacy, personhocd, and association). How consistent other paternalistic measures are with the liberal principles sketched here raises deep and difficult issues beyond the scope of this Article. For a fuller discussion, see Kelman, Regulation and Paternalism, 29 PUB. POL'Y 219 (1981) (regulation which appears to be paternalistic may be justified on other grounds); Kennedy, Distributive and Paternalist Motives in Contract and Tort Law, with Special Reference to Compulsory Terms and Unequal Bargaining Power, 41 MD. L. REV. 563 (1982) (endorsing certain forms of paternalism as expressing and securing values of solidarity).

The version of liberalism developed in the text is premised on a pluralistic conception of the good. It rejects the view that moral values are wholly subjective and cannot form a rational basis for collective action. Difficulties, of course, arise when the collective action in question is coercively enforced on dissenters by government. 
then consumers are being forced to devote their resources to advancing the private ends that the truckers pursue with their monopoly profits. This transfer violates neutrality. ${ }^{13}$

These principles do not necessarily rule out income taxation and a welfare state. ${ }^{14}$ But they require that "taxation by regulation" and other transfers (or asserted restitutions) be justified on the basis of some general societal conception of the right or the good.

Although logical corollaries, the principle of neutrality and the prohibition against coerced private wealth transfers seem, paradoxically, to contradict one another. Neutrality demands that regulation secure the "public interest" by advancing some general conception of the good; any such conception is, however, controversial, and the decision to invoke it will thus run afoul of the neutrality principle. On the other hand, if government seeks to avoid this difficulty by furthering purely private ends, it is in danger of violating the prohibition of coerced private wealth transfers by employing governmental powers to aid certain groups in their struggle for material advantage over other groups. The entitlement, wealthmaximizing, and non-commodity values conceptions of regulation can each be viewed as responses to this paradox.

At least since Dicey, critics have claimed that administrative regulation poses an especially serious threat to these two liberal principles of neutrality and avoidance of coerced private wealth transfers. ${ }^{15}$ In the United States, attempts to contain this threat have relied, for the most part, on procedural controls. Attention has focused on agency decisionmaking procedures, internal separation of functions, and the availability and scope of

13. Cf. Loan Ass'n v. Topeka, 87 U.S. (20 Wall.) 655 (1874) (voiding use of city's power to issue bonds because power was used for private benefit). Suppose, for example, a lobby of proselytizing health food faddists persuades the Food and Drug Administration to ban all processed foods on the ground that non-processed foods are inherently worthier because they are "natural." Such a violation of neutrality could also be viewed as a coerced sacrifice of the resources and opportunities of processed-food producers and consumers to the private advantage of the health food supporters.

14. Taxes are necessary to provide certain collective goods, such as public security. In addition, the opportunity for each citizen to realize her conception of the good may be grounded in a right to a minimum income, or to certain necessities such as food and shelter. See C. FRIED, RIGHT AND WRONG 134-50 (1978); Michelman, The Supreme Court, 1968 Term-Foreword: On Protecting the Poor Through the Fourteenth Amendment, 83 HARV. L. REV. 7 (1969).

15. See A. DICEY, INTRODUCTION TO THE STUDY OF THE LAW OF THE CONSTITUTION 183-201 (1915). This belief has often been reflected in a sharp contrast between regulatory law and the common law. The latter has been regarded as a reasoned system of rights and duties exemplifying the liberal conception of law, whereas regulatory law has been conceived of as an inherently discretionary and hence unpredictable engine of political power. See, e.g., F. HAYER, THE ROAD TO SERFDOM (1944); Pound, For the "Minority Report," 27 A.B.A. J. 664 (1941). Some critics, however, have turned the analysis used to discredit regulatory law against law in general. They view all forms of law, including judge-made law and statutory interpretation, as discretionary, "political," and violative of liberal principles as regulatory law. See, e.g., THE POLITICS OF LAW (D. Kairys ed. 1982); Kennedy, supra note 12. This Article does not address this important controversy; it examines the consistency of regulation with liberal principles without attempting to decide whether regulation is a special case. 
judicial review. The two liberal principles have also been reflected in substantive constitutional requirements that state action be neutral and that state power to regulate, to tax and spend, and to condemn property be exercised for public purposes. ${ }^{16}$ These requirements have not, however, been enforced to limit the growth of administrative power in any major way. The requirement of neutrality has been largely confined to a few special subjects, such as race and gender discrimination, religion, and free expression; ${ }^{17}$ the public purpose requirement has been dormant. ${ }^{18}$ Broad statutory delegations of authority to agencies have made courts reluctant to confront the elected political branches with a constitutional blunderbuss by invalidating such statutes. Instead, judges have used selective, nonconstitutionally based techniques of review and control-including procedural requirements and statutory interpretation-to deal with the most troubling exercises of the delegated power by bureaucratic agencies.

This strategy has been accompanied, during the past fifteen years, by an accelerating loss of public and professional confidence in the performance of regulatory agencies. Economists and public interest advocates have expressed concern with the "capture" of regulatory power by factional interests. ${ }^{19}$ Courts have sought to promote "interest representation" and

16. See Loan Ass'n v. Topeka, 87 U.S. (20 Wall.) 655, 664 (1874) ("[w]e have established . . . beyond cavil that there can be no lawful tax which is not laid for a public purpose") (emphasis in original); T. COOLEY, CONSTITUTIONAL LIMITATIONS WHICH REST UPON THE LEGISLATIVE POWER OF THE STATES OF THE AMERICAN UNION, 258-64 (state can legislate only "for the public good, and not for the benefit of individuals"); Sunstein, Public Values, Private Interests, and the Equal Protection Clause, 1982 SUP. CT. REV. 127, 128 (equal protection clause prohibits unprincipled distribution of public goods to private parties).

The federal structure of American government, the separation of powers within the national government, and the non-delegation doctrine can be understood as wholesale strategies designed to reduce the danger of violations of the two liberal tenets. The danger that broad regulatory statutes could be used for illiberal ends is a traditional justification for invalidating such statutes as unconstitutional delegations of legislative authority.

17. A broader application of the neutrality principle is reflected in decisions such as Meyer v. Nebraska, 262 U.S. 390 (1923), and Pierce v. Society of Sisters, 268 U.S. 510 (1925), which struck down state restrictions on private education as violative of the Fourteenth Amendment. For an effort to explain Roe v. Wade, 410 U.S. 113 (1973), which invalidated state abortion statutes, in these terms, see Tribe, The Supreme Court, 1972 Term-Foreword: Toward a Model of Roles in the Due Process of Life and Law, 87 HARV. L. REV. 1, $40-43$ (1973).

18. There are, however, some signs of the requirement's revival. See, e.g., Virginia State Bd. of Pharmacy v. Virginia Citizens Consumer Council, Inc., 425 U.S. 748, 764-65 (1976) (free flow of commercial speech is "a matter of public interest"); Home Box Office, Inc. v. FCC, 567 F.2d 9 (D.C. Gir.) (FCC must consider television viewer choice and welfare, rather than broadcast industry protection, as dominant consideration in making policy), cert. denied, 434 U.S. 829 (1977).

For recent discussion of the public purpose requirement in the context of economic regulation, see Linde, Due Process of Lawmaking, 55 NEB. L. REV. 197 (1976) (discussing judicial review of legislative means and goals); Mashaw, Constitutional Deregulation: Notes Toward a Public, Public Law, 54 TUL. L. REV. 849, 876 (1980) (promoting "constitutional right to demand that public law be public regarding"); Michelman, Politics and Values or What's Really Wrong with Rationality Review?, 13 CREIGHTON L. REV. 487, 509 (1979) (criticizing welfare economic analysis for ignoring non-individualist consensus).

19. See, e.g., R. Fellmeth, The INTERSTATE COMMERCE OMmission 1-40 (1970) (describing transportation industry's influence on ICC); G. STIGLER, THE CITIZEN AND THE STATE (1975) (argu- 
have adopted a "hard look" standard of review in order to control administrative policy-making. ${ }^{20}$ Public distrust of regulatory performance has become an important factor in national politics. These developments reflect, I believe, a widespread perception that existing regulatory programs violate liberal principles. Regulation is viewed as a self-serving tool, manipulated either by well-organized economic interest groups to increase their wealth, ${ }^{21}$ or by ideological factions to impose their partisan values on society. ${ }^{22}$ These reactions attest to the continuing vitality of liberal principles.

\section{B. The Historical Context of Liberalism and Regulation in the United States}

The abstract account of liberal principles and legal doctrine sketched above must be placed in the historical context of American conditions and experience. To equate liberalism with a society in which solitary, atomized individuals independently pursue a private and subjective conception of the good is not only a caricature, but a highly misleading one. American liberalism has embodied a more ample vision, one based upon associational values. Hostility to organizations standing between the citizen and the central government has been more characteristic of the monarchical and revolutionary nation states of Europe than of the United States. Lacking a feudal past and the need to extirpate it, and facing the need to accommodate a variety of dissenting religious sects, Americans developed a social, political, and legal system in which different local communities and voluntary organizations each collectively pursued divergent conceptions of the good. ${ }^{23}$ This pattern expresses the liberal premise that the good is both plural and an appropriate object of concerted discussion and action. The values associated with decentralized, associational liberalism have, however, been undermined by industrialization and the rise of nationwide markets, and by regulatory responses to the social and economic effects of these developments.

ing that regulation is generally conducted for the benefit of regulated industry rather than the public). 20. See Stewart, supra note 6; Stewart, Vermont Yankee and the Evolution of Administrative Procedure, 91 HARV. L. REV. 1805 (1979) (shift from adjudication to rulemaking demands new procedures to create reviewable records).

21. For a vivid journalistic account of the "special interest state" in operation, see Drew, $A R e$ porter at Large, Phase: Engagement with the Special Interest State, NEW YORKER, Feb. 27, 1978, at 64.

22. See Law, Rethinking Sex and the Constitution, 132 U. PA. L. REV. 955 (1984); Weaver, Regulation, Social Policy, and Class Conflict, 50 PUB. INT. 45, 57-61 (1978).

23. See O. HANDLIN \& M. HANDLIN, PATHS TO FREEDOM (1961); A. SCHLESINGER, PATHS TO THE PRESENT 23-49 (1949); C. SMITH, PRIVATE ASSOCIATIONS, PERSPECTIVES ON THE LITERATURE (1972). The most famous contemporary account from the 19 th century is A. DE TOCQUEVILLE, DE MOCRACY IN AMERICA (H. Reeve trans. 1841). For a skeptical view of the virtues of voluntary associations in the contemporary context, see M. HAUSKNECHT, THE JOINERS (1962). 
De Tocqueville celebrated the instinct for associational selfdetermination as a distinctively American trait. ${ }^{24}$ In the first century of the Republic, such activity was decentralized and carried on by relatively small groups. Some groups were governmental in form, such as towns, cities, or special-purpose authorities like school boards. Others, such as churches, fraternal orders, working-men's associations, unions, and private colleges, were non-governmental.

This decentralized system suited an increasingly diverse country. It also provided a social context that nurtured a more enriched form of personal and collective life than could occur in an arid, impersonal society of isolated and self-seeking individuals. ${ }^{25}$ Many of the voluntary associations had mutual self-improvement as a principal goal-witness churches, working-men's associations, and Chautauquas. Decentralized, small-scale government and participation in voluntary associations promoted civic virtue. ${ }^{26}$ In an environment of ethnic, religious and geographical differences, this decentralized, associational form of liberalism promoted considerable diversity in community values and cultures.

The tradition of decentralized association was by no means entirely benign; we must avoid romanticizing the past. Small towns and churches or other groups could impose a suffocating conformity. Many individuals lacked the mobility required to enjoy diversity. Ethnic, religious, and geographical differences often bred mutual intolerance among groups and communities. ${ }^{27}$ These drawbacks have diminished over time with improved communications, greater mobility of labor and capital, and the development and integration of markets. But the rise of national markets-and the centralized systems of regulation which they have provoked-has also undermined the traditional system of diverse, decentralized associations and communities, and diminished its capacity to nourish a more ample form of liberalism. ${ }^{28}$

We can see some of the costs of emerging national markets in both the

24. See 2 A. DE TOCQUEville, supra note 23 , at 114-28. This instinct for private ordering expressed itself during the progressive era in opposition to centralized government economic management and intervention. See R. KELLEY, supra note 7, at 30-35.

25. See O. HANDliN \& M. HANDLIN, supra note 23; W. MCWilliaMS, supra note 5, at 508 . The Handlins make the intriguing suggestion that Jacksonian opposition to government economic intervention and management on the ground that it redistributed wealth in favor of "special interests" was linked to the growing cultural pluralism of the nation, which impeded agreement on government policy.

26. See 2 A. DE TOCQUEVILLE, supra note 23 , at 117-18.

27. See, e.g., I. Herron, THE SMALl TOWN IN AMERICAN LiTERATURE 91, 212, 368-69, 382-83 (1939) (describing small towns" "rigidly dogmatic moral code, provincialism, and vitiating dullness"); Berthoff, Peasants and Artisans, Puritans and Republicans: Personal Liberty and Communal Equality in American History, $69 \mathrm{~J}$. AM. HIST. 579 (1982); Chesler, Imagery of Community Ideology of Authority: The Moral Reasoning of Justice Burger, 18 HARV. C.R.-C.L. L. REV. 457 (1983).

28. See S. HAYS, THE RESPONSE TO INDUSTRIALISM 1885-1914, at 4-6 (1957); I. HERRON, supra note 27, at 352-53; W. MCWILliAMS, supra note 5, at 67-68, 508-09 (1974). 
communications and environmental areas. Seventy-five years ago, Americans relied predominantly upon local newspapers for political information. ${ }^{29}$ They also relied upon local initiatives, largely undertaken by voluntary associations, for recreation and entertainment. Today, they rely principally on national network television for both news and entertainment. This development has brought with it tremendous advantages-higher-quality productions, a cosmopolitan perspective, and a greater range of available information and experience. But it has also had important drawbacks. Civic virtue-personal responsibility for, and participation in, collective decisionmaking - has been eroded by the relative dearth of community-based political information and cultural activity on television. In the view of many critics, variety and aspiration for excellence have been sacrificed to a passive technology of culturally flabby entertainment. ${ }^{30}$ The homogenizing forces of a mass market of advertisersupported programming have overtaken decentralized diversity.

An analogous development is discernible in the environmental context. When industrial technologies were less developed and economic markets less integrated, local and regional economies fostered considerable physical and social diversity among the industrial and commercial northeast, the plantation and share cropper south, the family farms of the midwest, and the natural resource-based economies in the west. The development of national markets and new technologies has reduced, if not eliminated, variances among regional economies and patterns of life. ${ }^{31}$ As a result, geographical diversity in community cultures and values has declined. Communities that seek to preserve distinctive, high-quality environments by imposing relatively stringent environmental controls risk a loss of industry, development, and employment to communities with more lax standards. ${ }^{32}$ This threat acts as an homogenizing force that tends to produce diminished environmental quality everywhere.

The "market failures" created by the development of new products and technologies and the rise of mass markets in these and other areas provoked the formation of centralized regulatory regimes. ${ }^{33}$ For example, the development of broadcast technology without a corresponding property

29. See J. SIM, THE GRASS ROOTS PRESS: AMERICA'S COMMUNITY NEWSPAPERS 39-42 (1969); Bagdikan, Grass Roots Press, 229 HARPERS 102 (1964).

30. See CaRnegie Commission Report on Educational Television (1967); F. FRiendly, DUE TO CIRCUMSTANCES BEYOND OUR CONTROL . . ., 266-325 (1967); N. MINOW, EQUAL TIME 52 (1964); Note, A Regulatory Approach to Diversifying Commercial Television Entertainment, 89 YALE L.J. 694, 694-95 (1980) and sources cited therein.

31. See G. JACKSON, RegIonal DIVERSITY 134 (1981); Rosenberg, History and Perspective, in Regional Conflicts and National POliCY 18 (K. Price ed. 1982).

32. See E. REHBINDER \& R. STEWART, THE IMPLICATIONS OF THE AMERIGAN FEDERAL EXPERIENCE FOR EUROPEAN INTEGRATION: ENVIRONMENTAL LAW (forthcoming).

33. See S. BREYER, supra note 1. 
rights system in the electromagnetic spectrum created chaos that triggered a demand for regulation. In the environmental area, pollution and toxic waste spillovers became conspicuous examples of market failures that led to calls for regulation.

Such regulatory programs exhibit strong centralizing tendencies, attributable to the national scope of the markets which they are designed to regulate. Problems created by interference, and scale economies in broadcasting, demand a regulatory program that is national in scope. ${ }^{34}$ Interstate mobility of products, capital, and pollution undermine local or state environmental initiatives, and invite nationwide solutions. ${ }^{35}$ As a result, federal regulatory programs administered by federal bureaucracies and federal judges have, to a considerable degree, displaced decentralized decisionmaking.

Believers in a more ample form of liberalism could adopt three responses to the homogenization and centralization engendered by mass markets and regulation. The first would be to abandon regulation on the supposition that regulation is a greater threat to liberal values than is the totally unregulated market. ${ }^{36}$ The second would be to effect a radical disaggregation of economic and regulatory activity, substituting self-management by small groups and communities for large-scale business and administrative organizations. Such disaggregation would aim to restore the conditions that fostered associational liberalism. ${ }^{37}$ The third is to accept the development of national markets, large-scale organizations, and a substantial degree of regulation, but to attempt, within that basic framework, to promote the values historically associated with decentralized associational liberalism. ${ }^{38}$ I focus on this last strategy because I think it provides the most likely prospect for advance. ${ }^{38}$

34. The problem of broadcast interference might be dealt with by developing a system of property rights in the spectrum that does not rely on administrative regulation. See Coase, The Federal Communications Commission, 2 J.L. \& ECON. 1, 25-35 (1959). But this system would also have to be national in scope and uniform in its features.

35. See E. REHBINDER \& R. STEWART, supra note 32.

36. See F. HAYEK, supra note 15 , at 88-100; R. HESSEN, IN DEFENSE OF THE CORPORATION (1979).

37. See Frug, The City as a Legal Concept, 93 HARV. L. REV. 1057 (1980); Unger, supra note 2, at 593-97. It has been suggested that the displacement of small-scale, self-managed 19th-century enterprise by large-scale enterprise was not inevitable. See S. HAYS, supra note 28, at 33-34. But see A. CHANDleR, THE Visible HAND: THE MANAGEMENT REVOlUTION IN AMERICAN Business 17-19 (1977). The compatibility of small scale enterprise and governance with national or international factor markets remains a critical and largely unexplored problem for this alternative.

38. Such an alternative should not, however, ignore the considerable but as yet unexploited opportunities for a greater measure of decentralization in existing federal regulatory programs. Many of these opportunities involve the use of economic incentives as an alternative to the current "command and control" system of regulation. See Stewart, Regulation, Innovation, and Administrative Law: A Conceptual Framework, 69 CALIF. L. REV. 1259, 1263 (1981).

39. This is not the occasion to undertake an examination of the first two alternatives. The first, to the extent that it would, for example, abrogate environmental regulation, seems unacceptable in terms 


\section{Regulatory Programs as Deals}

In this and succeeding sections of the Article, I examine several different conceptions of government that relate regulation to traditional liberal principles and offer a foundation for regulatory jurisprudence. This section examines the deals conception, which sees regulatory statutes (like all legislation) as nothing more than private interest group bargains which ought to be judicially enforced as such.

On its face, this thesis appears inconsistent with liberal principles. It seemingly endorses factional exploitation of government power to effect private wealth transfers or to impose sectarian ideologies on others, and fails to provide a public justification for the government's exercise of force. The deals conception can, however, be understood as a "minimalist" version of liberalism. Because ideas of the good are plural, government can, in this view, be nothing more than a precarious system of mutual but competitive advantage among different factions, each of which seeks to capture all of the gains from cooperation in order to advance its own wealth or idea of the good. ${ }^{40}$

In the deals conception's starkest form, individuals and organizations regard government decisions in the same way they regard production and consumption choices made in the private market-as an opportunity to increase their wealth or preference satisfaction. Politics thus becomes a contest among actors for the "capture" and exploitation of regulatory and taxing and spending powers. Unless it has dictatorial power, a faction is likely to enhance its prospects in the struggle by entering into alliances and bargains with other factions. Because it assumes that consensus on a single common conception of the good is impossible, the minimalist liberal position concludes that the only function that government can have is to facilitate and enforce whatever mutually self-interested deals factions happen to strike.

Richard Posner and William Landes have argued that this deals conception provides a sound and appropriate judicial framework for public law. ${ }^{41}$ In their view, law consists of the authoritative, coercively binding

both of commodity and non-commodity values. No one has yet sufficiently developed the second alternative to permit me to assess it here.

40. The philosophical background of the minimalist position, which ultimately traces back to Thomas Hobbes, is examined in A. MACINTYRE, AFTER VIRTUE (1981) and T. SPRAGENS, THE IRONY OF LIBERAL REASON (1981).

41. Landes \& Posner, The Independent Judiciary in an Interest-Group Perspective, 18 J.L. \& ECON. 875 (1975); see also R. POSNER, ECONOMIC ANALYSIS OF LAW 405-17 (2d ed. 1977). Landes and Posner's early work does not take explicit account of the ideologue-the person or group who wishes to advance certain moral and ideological goals or ideals rather than personal or organizational wealth. But the basic conception of legislation as a "deal" among competing interests can-at a considerable cost in predictive power-be expanded to include ideological as well as economic factors. In a recent article, Judge Posner has explicitly taken this step, revising his earlier views. See Posner, 
deals struck by the contending factions in the political market for public power. Just as courts enforce private contractual deals, so should they enforce constitutional, statutory, and administrative deals, as understood at the time of their adoption or enactment. Posner and Landes assert that this approach best conforms to political reality and the intent of lawmakers, provides a relatively objective and non-"political" basis for the exercise of judicial power, and promotes political stability. ${ }^{42}$ An analogous, if less stark, view informs the recent work of John Hart Ely. ${ }^{43}$

This view of the political process, which has a long and distinguished pedigree in the political science literature, ${ }^{\mathbf{4}}$ has great plausibility. Eco-

Economics, Politics, and the Reading of Statutes and the Constitution, 49 U. CHI. L. REV. 263, 27072 (1982). There, he classifies statutes into four groups: (1) "public interest, economically defined" statutes (such as antitrust laws which advance consumer welfare); (2) "public interest in other senses" statutes (e.g., a progressive income tax designed to implement a just distribution of income); (3) "public sentiment" statutes (e.g., forbidding the sale of pornography); and (4) "narrow interest group legislation" (e.g., the Civil Aeronautics Act of 1938).

The distinction between categories (2) and (3) is obscure, and even that between (1) and (4) is ambiguous. At some points in the article, Judge Posner seems to argue that the courts should take a quite different approach in interpreting "public interest" statutes from that taken with statutes that represent interest group "deals." But he fails to provide any workable criteria to distinguish these two categories of statutes, leaving his claim for different interpretation of the two types largely useless as far as the courts are concerned. In the effort to go beyond his original "deals" conception in order to deal with a broader and more realistic range of statutes, Judge Posner appears to have sacrificed much of the coherence and power of his earlier approach.

42. A modified version of Judge Posner's views is found in Michelman, Constitutions, Statutes, and the Theory of Efficient Adjudication, 9 J. LEGAL STUD. 431, 440-42 (1980).

43. J. ELY, supra note 2; Ely, Democracy and the Right to be Different, 56 N.Y.U. L. REV. 397 (1982). Although Dean Ely does not embrace an economic model of behavior, politics in his neopluralist universe also consists of a struggle among interest groups for control of legislative power.

Ely explicitly views the legislative process as a pluralistic system of bargaining and logrolling. The courts' role is to promote rough equality of access to this process by, for example, imposing a oneperson, one-vote rule of representation and preventing the exclusion of, or systematic discrimination against, "discrete and insular minorities" such as blacks or Hispanics. See J. ELY, supra note 2, at 73-104. In the context of administrative law, Ely would have the courts apply the non-delegation doctrine with considerable rigor in order to ensure that legislation is relatively specific. Id. at 73-104, 131-34. While Ely does not explicitly deal with statutory interpretation, his entire "representationreinforcing" strategy, as well as his skepticism about "fundamental values," would seem to imply that courts should ordinarily strive to give effect to the statutory compromise-the "deal," if you will-which emerges from the interest-group struggle in the legislature.

Ely does not advocate, however, that courts treat statutes as deals among self-regarding interests. Elsewhere, he proceeds on the orthodox premise that courts should interpret statutes in accordance with the public values that the statutes might serve. See Ely, The Irrepressible Myth of Erie, 87 HARV. L. REV. 693 (1974). This premise suggests that courts should regard participants in the political process as motivated by different conceptions of the public good. Statutes may then be regarded as "deals" or compromises among competing public-spirited factions. But this shift does not solve and may indeed aggravate the problem of indeterminacy that is inherent in the "deals" approach. See infra pp. 1551-53. One still requires suppletive principles-such as the conceptions examined in this Article-to resolve the indeterminacy. The problem with Democracy and Distrust is precisely that such conceptions do not exist or at least are not accessible to courts as a justifiable basis for the exercise of judicial power.

44. See, e.g., A. BENTLEY, THE PROCESS OF GOVERINMENT $370-72$ (1908) (describing legislative process as interplay of group interests); E. HERRING, PUBLIC ADMINISTRATION AND THE PUBLIC INTEREST (1936) (legislature has primary responsibility for achieving compromise among class and sectional interests); D. TRUMAN, THE GOVERNMENTAL PROcEss: POLITICAL INTERESTS AND PUBLIC OPINION (1951) (describing tactics of interest group influence). 
nomically self-interested actors, ideologues, and politicians who seek to barter their competing interests are indeed the most active participants in regulatory politics. ${ }^{45}$ Regulatory decisionmaking usually does involve a struggle among competing economic and ideological factions, each seeking to use the coercive power of government to advance its own ends. There are, however, three major flaws in the deals thesis that sharply limit its suitability as an analytic framework for regulatory jurisprudence: inaccuracy, indeterminacy, and illiberality. The "realism" of the deals thesis is no less flawed than its normative premises.

\section{A. Inaccuracy}

This thesis fails to provide an adequately accurate account of the legislative process. While organized private economic and ideological interests play a central role, ${ }^{46}$ statutes often emerge from a far more complex and open-textured process than that which characterizes the private commercial transactions that provide the model for the deals conception of public law. Legislators and executive officials act as entrepreneurs in an environment in which often inchoate public opinions, reactions of the media and "opinion leaders," the reciprocal dynamics of the legislative process, background expectations, the pressure of underlying socio-economic trends, and sheer chance also play important roles. ${ }^{47}$ It is a gross oversimplification to regard most statutes as the product of a bargain among a few readily identifiable organized interests such as environmental groups and automobile manufacturers. ${ }^{18}$ Broadcast regulation cases exemplify the futility of attempting to resolve regulatory controversies by reference to the private interest deals supposedly embodied in statutes. It is difficult to discern any deal in the 1934 Communications Act that is helpful in resolving contemporary regulatory issues, beyond a vague, widely-shared

The "interest group" approach has been elaborated with great methodological sophistication by the new public choice theory, which uses microeconomic premises to analyze government institutions and decisions. See J. BuChanaN \& G. TUllock, THE CALGulus of CONSENT (1962); Stigler, The Theory of Economic Regulation, 2 BELL J. ECON. 3 (1971).

45. See E. KRASNOW, L. LONGLEY \& H. TERRY, THE POLITICS OF BROADCAST REgULATION (3d ed. 1982); Birnbaum, Crop Controversy: Farm, Budget Officials Clash on Supply Curbs by Marketing Boards, Wall St. J., Dec. 7, 1982, at 1, col. 6; Drew, supra note 21, at 64.

46. Specific statutory provisions-like those in the Clean Air Act protecting the jobs of Ohio coal miners-sometimes express clear victories by, or explicit compromises among, private interest groups. See B. ACKERMAN \& W. HASSLER, CLEAN COAL/DIRTY AIR 44-48 (1981).

47. For accounts of the complex factors, in addition to special interest "dealing," that underlie social legislation, see B. Ackerman \& D. Elliott, Toward a Theory of Statutory Evolution: The Case of Environmental Law (unpublished manuscript on file with the Yale Law Journal); H. HECLO, MODERN SOCIAL POLITICS IN BRITAIN AND SWEDEN 284-326 (1974).

48. On the other hand, if the notion of "interests" is expanded to include all of the other elements in such a complex process, the deals concept becomes hopelessly indeterminate. See infra pp. 1551-53. 
concern to order chaos and avoid the vesting of property rights in the electromagnetic spectrum.

It is also significant that we do not affirm a deals conception in public discourse. This practice reflects the important fact, which the deals conception disregards, that most individuals draw a distinction between the considerations of self-interest they follow in making individual production and consumption decisions and the considerations that are relevant to decisions of public policy. Most citizens do not equate voting with shopping. ${ }^{99}$ Legislators and administrators are accordingly at pains to explain and justify their actions as securing rights or advancing some public good, not as cementing a deal among private interests. ${ }^{80}$ The persistence of public interest discourse on the part of legislators and administrators is contrary to what the deals thesis would predict. If government simply acts as a broker of private bargains, we would instead expect that legislative and administrative "brokers" would ensure reliable judicial and agency enforcement of the bargains they arrange by explicitly identifying the private interests that are party to the bargain and specifying how a statute or regulation was designed to promote or accommodate those interests. ${ }^{\text {s1 }}$

Moreover, decisional law demonstrates that courts do not regard the regulatory enterprise as merely enforcing deals. Instead, they see the government's role as identifying, assessing, and weighing the relevant public objectives that justify regulation. ${ }^{62}$ Litigants, naturally enough, pitch their claims in such terms. Not only would a deals thesis involve a completely different mode of discourse and analysis, but it would imply that courts should focus on issues they rarely address, such as the precise objectives and positions of the various interest groups politically active at the time a statute was enacted. ${ }^{\text {ss }}$

49. See Michelman, supra note 14, at 24-25; Sen, Rights and Agency, 11 PHIL. \& PUB. AFF. 3 (1982). Of course, there is a human tendency to equate the general interest with one's own. Ideologues may even more readily identify the community's values with theirs. An adversary system of lobbying and litigation encourages these tendencies. When officials of corporations and other large bureaucracies engage in such advocacy on their behalf, organizational and psychological pressures operate to squeeze out an independent consideration of the general interest.

50. As Frank Michelman has pointed out, however, this is not to say that interest groups eschew the language of rights. Having their interests protected by a set of statutory entitlements would ensure that their interests will trump other factors considered by the administrative decisionmaker. See Michelman, In Pursuit of Constitutional Welfare Rights: One View of Rawls' Theory of Justice, 121 U. PA. L. REV. 962, 997-1003 (1973).

51. The deals conception cannot dismiss public interest discourse as mere window dressing. A deals conception is normatively justified, if at all, by a claim that enforcement of the bargains struck in a political arena open to all interests is more likely to advance individuals' interests than any alternative conception of legislation and administration. If the general public accepts and acts on this conception of the political process, why is "window dressing" needed? If the public does not, then the normative claim for the deals approach is seriously compromised; the inference is that only certain players understand the true nature of the game, and accordingly enjoy a decisive advantage in it.

52. See Sunstein, supra note 16, at 132-34 (discussing rational relationship test).

53. Judge Posner's claim that courts are institutionally incapable of this inquiry is not very per- 


\section{B. Indeterminacy}

A second and related flaw in the deals approach is the inevitable indeterminacy of statutes and regulations. This indeterminacy requires courts engaged in interpretation of statutes and review of administrative action to develop and apply suppletive principles incorporating general social values which the deals approach ignores.

A statute is a curious form of "contract." How does one identify the parties to it? Those active in the legislative process typically include private groups, state and local officials, representatives of the executive branch, and the legislators themselves. Public opinion hovers hazily in the background. As the circle of participants and constituencies widens, it becomes increasingly difficult to regard the statute as an identifiable deal negotiated among discrete actors. Verisimilitude can be achieved only at the price of indeterminacy.

The multiplicity of "parties," compounded by the high costs of legislative agreement, results in vague or ambiguous statutes. Moreover, most statutes must guide behavior over a long period of time. Even if ascertainable, the contemporaneous "intent" of the "parties" will often give little aid in determining what content should be given to a statute years later under new and unforeseen conditions. ${ }^{\mathrm{s}}$

In contract law, courts have generated a variety of suppletive principles to deal with the inevitable problems of vagueness, ambiguity, and unanticipated or unprovided-for cases. These principles, including norms of good faith and restrictions on overreaching, are a judicial incorporation of applicable social values. ${ }^{.5}$ Adjudication shapes the otherwise ambiguous deals made by the parties in accordance with such understandings.

Application of a contractual approach to legislation would necessarily

suasive. He first argues that courts lack the institutional competence to discover the actual origins of a law, and so must rely on public documents. See Posner, supra note 41, at 272-73. But "public documents" certainly include testimony by interest groups in legislative hearings; furthermore, courts could also look at trade association publications and other interest group position papers, newsletters, speeches, and so forth. While it would not be simple to reconstruct the configuration of interest group positions with respect to legislation, it is commonly undertaken all the time by historians and seems no more difficult than many other tasks that courts undertake.

The second reason Judge Posner advances for limiting courts to statutory language and legislative history is a "normative theory of democratic politics." Id. at 273 . Because most voters are relatively ignorant about the actual background of legislation, judicial interpretations based on such background would unduly favor well-organized interest groups. This "normative theory," however, appears to be totally inconsistent with the "deals" approach originally advocated by Judge Posner and still retained in large part by him, and he fails to explain why courts do or should embrace it.

54. See G. CALABRESI, A COMMON LAW FOR THE AGE OF STATUTES 2 (1982). Landes and Posner also acknowledge the problem of obsolescence and indeterminacy. See Landes \& Posner, supra note 41 , at 879 .

55. See E. FARNSWORTH, CONTRACTS 479-501 (1982) (interpretation of vague or ambiguous terms); id. at 523-25, 526-34 (courts' creation of "implied" terms and duties to deal with omitted cases); id. at 660-79 (courts' treatment of mistake, impossibility, and frustration). 
involve analogous suppletive principles. Because of the greater likelihood of ambiguity, vagueness, and unanticipated and unprovided-for cases in the statutory context, such suppletive principles are correspondingly more important. In a society such as our own, these principles would necessarily incorporate liberal background understandings of the basic purposes of regulation. ${ }^{58}$

The problems posed for the deals approach by statutory vagueness, ambiguity, and unanticipated or unprovided-for cases cannot be finessed by the supposition that the deal involved a delegation of all such questions for decision by the responsible administrative agency. ${ }^{57}$ The extent and terms of any such delegation must be decided by someone. Our consistent administrative law practice-presumably part of the background against which any deal is made-points to the judiciary as the institution to make this determination. But the deals approach all too often fails to live up to its promise of providing courts with a determinate, "value-free" basis for making such determinations.

The FCC's assertion, during the 1960's and 1970's, of power under the Communications Act of 1934 to regulate cable television as ancillary to its regulation of over-the-air broadcasters provides an example of this problem. The statute, enacted when television was in its infancy and long before the rise of cable technology, authorizes the FCC to regulate broadcasting in the "public convenience, interests, or necessity . . ." Th8 The Act's history makes clear that it was not designed to protect existing broadcasters against competition. ${ }^{59}$ Shall the court say that the economic competition between cable and traditional broadcasting nonetheless supports the Commission's assertion of jurisdiction? Or that the failure to deal explicitly with new technologies in the 1934 Act excludes it? Or that the issue should be decided as the 1934 Congress would have done, had it foreseen it-an inquiry that risks incoherence? Or that it all depends

56. The more firmly established these principles, the more justified courts would be in applying them, unless there is a clear statement in the relevant statute to negate them. See H. HART \& A. SACKS, THE LEGal PROCESs 1240-41 (Tent. ed. 1958).

57. Nor can it be made to disappear by extending the doctrine against delegation of legislative power to require greater statutory specificity. See Stewart, supra note 6, at 1693-97. Dean Ely takes a different view, believing that courts can successfully force legislatures to enact detailed and specific statutes. See J. ELY, supra note 2, at 131-34.

58. 47 U.S.C. $\$ 307$ (a) (1982).

59. See Coase, supra note 34 , at $8-9$. Coase points out that a principal reason for Congress' creating a regulatory program to deal with the problem of competition for scarce spectrum space, rather than awaiting common law development of the property system, was fear that the latter system would give existing broadcasters vested property rights in the spectrum and prevent changes in spectrum allocations in response to changing technologies and social considerations. The perceived need for flexibility was explicitly reflected in statutory provisions limiting the broadcasting license term to three years (since enlarged to five) and bravely stating that a license award was not to be construed as a grant of property rights in the spectrum. See Communications Act of 1934, $\$ 307$, ch. 652, 48 Stat. 1083 (codified as amended at 47 U.S.C. $\$ 307$ (d) (1982)). 
upon a particularized ássessment of the justifications for, and likely consequences of, the Commission's assertion of jurisdiction? ${ }^{60}$ The deals approach cannot answer these questions; their resolution requires the judicial application of suppletory principles incorporating public values other than simple bargain-enforcement.

Similar difficulties in applying the deals approach arise with respect to procedural questions. The largely judge-made doctrines governing intervention in agency proceedings and standing to secure judicial review have a major impact on regulatory outcomes. When the Gommunications Act was passed in 1934, consumers and others not directly subject to regulation could generally not intervene in regulatory agency proceedings or seek judicial review. Courts have since liberalized the law. ${ }^{61}$ Ought today's courts, deciding broadcast cases today in which viewer groups seek intervention in and judicial review of FCG decisions, apply the procedural law of 1934, on the premise that it was part of the statutory deal? Or ought they apply the law as subsequently liberalized, on the premise that continued flexibility was part of the deal?62 The Act itself does not-indeed, by the logic of self-reference, cannot-resolve the question. The deals approach, which promises objectivity and predictability, again provides no guidance.

\section{Illiberality}

The stark form of the deals conception advanced by Landes and Posner posits and enforces a vision of a society in which citizens use government power to prey on one another. Strong and well-organized interests enrich themselves and impose their sectarian values on the weak and less cohesive. Moreover, the private wealth-redistributing deals that the dominant interests arrange and the courts enforce as such diminish the economic welfare of society as a whole. ${ }^{63}$

Such a bleak ideal of society can only be justified on the basis of a highly pessimistic view of institutional reason. It assumes that values are totally arbitrary and subjective, and that government can accordingly do no more than secure a minimum of stability and wary cooperation by

60. For a sample of judicial efforts to deal with the cable television issue, see FCC v. Midwest Video Corp., 440 U.S. 689, 704-07 (1979); United States v. Midwest Video Corp., 406 U.S. 649, 671-75 (1972). For discussion of the principles applied by the courts in the communications field generally-principles which include an aversion to private interest deals - see infra pp. 1579-81.

61. See Chayes, The Supreme Court, 1981 Term-Foreword: Public Law Litigation and the Burger Court, 96 HARV. L. REv. 4, 4-5 (1982); Stewart, supra note 6, at 1723-56.

62. The issue is further complicated by provisions in the Communications Act authorizing judicial review by license applicants or persons "adversely affected" or "aggrieved" by the Commission's decision. 47 U.S.C. $\S 402(b)(6)$ (1982). See Office of Communication of United Church of Christ v. FCC, 359 F.2d 994, 1000-06 (D.C. Cir. 1966) (discussing evolution of standing doctrine).

63. See J. BUChANAN \& G. TULLOCK, supra note 44; G. STIGLER, supra note 19. 
enforcing the mutually self-interested deals that emerge from a political struggle which serves as the surrogate for violence. ${ }^{64}$ It concludes that judges ought not attempt to promote the just or the good, for in seeking to impose their own subjective preferences on others they would introduce destabilizing uncertainty.

A conclusive refutation of this rationale would require a volume of philosophy (or an historical millenium) that has not yet appeared and likely never will. I limit myself to two claims. First, the deals approach misconceives the true sources of stability in a social and political order. In the face of rapid social and economic change, stability cannot be found in a practice of enforcing whatever deals powrerful interest groups may have struck at some often distant point in the past, even if one could identify such deals and their contemporaneous import. The effort to enforce such past deals can, in fact, be highly destabilizing. Given the inertia of the legislative process, why should subsequent players accept the particular deals that earlier players happened to strike simply because those deals came first? The deals thesis ignores this problem and supposes that social stability can be achieved only by resolving the balance between uncertainty and flexibility entirely in favor of the past's dead hand. ${ }^{65}$ The appropriate, if inevitably indeterminate, reference points for balance must be in socially embedded normative frameworks-such as entitlement, wealthcreation, and non-commodity values-that provide the sources of adaptive stability in the legal order.

The continuing power of these normative conceptions, illustrated in the later sections of this Article, gives rise to a second claim. The record of our society and its jurisprudence indicates that the deals approach takes too pessimistic a view of institutional reason. The American liberal tradition has, however imperfectly, advanced individual dignity and promoted the collective realization of both material and non-commodity values in ways that transcend what the deals conception can know or admit.

\section{The Continuing Relevance of the Deals Approach}

Despite these criticisms, the deals approach is not irrelevant to regulatory law. The logic of representative democracy requires a large scope for play among competing social and economic interests in shaping law.

64. See Michelman, Norms and Normativity in the Economic Theory of Law, 62 MINN. L. REV. 1015 (1978).

65. The premise of this argument, like that of Professor Calabresi's, see G. CALABREsI, supra note 54 , is the presence of a high degree of inertia in the legislative process. The many techniques, chronicled by Professor Calabresi, used by courts to avoid enforcing outdated statutes may reflect a judgment that such enforcement would be destabilizing. But a legislative process that instantly enacted contemporaneous shifts in public views would also be destabilizing. 
Moreover, political activity can be understood as a form of reciprocal education and collective self-determination integral to a more ample form of liberalism. ${ }^{66}$ Ideally, politics involves a dialogue among different publicregarding visions of liberal policy, rather than a struggle among privateregarding factions seeking to exploit government power for their own benefit. ${ }^{67}$ But our situation is not ideal. Although citizens do not equate voting with shopping, they do perceive and act on the premise that politics is, to a considerable degree, a struggle among competing factions. For the most part, courts in an imperfectly ordered democracy cannot sufficiently distinguish public-regarding from private-regarding legislation in order to invalidate the latter ${ }^{68}$ If Congress enacts into law an interest-group deal that passes muster under tolerant constitutional norms of public purpose and neutrality, courts enforce it.

Still, the law's great purpose is to justify and align the exercise of public force with public ends. In giving ongoing content to regulatory programs, courts accordingly proceed as if officials were pursuing public-regarding objectives. ${ }^{60}$ The deals thesis may contribute to a positive theory

66. See infra pp. 1566-76.

67. For a discussion of John Rawls' concept of a well-ordered society and its implications for the courts' role, see B. ACKeRnian, PRIVATE PROPERTY AND THE CONSTITUTION 5-39 (1977).

68. See supra notes 16-18.

69. See Sunstein, supra note 16, at 133-38 (discussing and explaining Supreme Court decisions).

In carrying out their "as if" enterprise, judges must make assumptions about how likely it is that the decisions they review will advance public, rather than parochial, private objectives. See B. ACKERMAN, supra note 67 , at 38. In addition, judges must be careful of undermining the authority of political institutions by expropriating their value-defining function. See Michelman, supra note 18, at 50810.

Moreover, there is a danger that the enterprise will be injected with hypocrisy, and citizens with cynicism, if the public objectives imputed to governmental decision are too greatly at variance with the actual sources and purposes. Rationality review of statutory constitutionality seeks to avoid this danger by openly admitting the "as if" character of the enterprise, refusing to examine actual motive, and simply positing the existence of facts which might sustain the statute. Federal administrative law, by contrast, has developed a "hard look" standard that probes more deeply, insisting that decisions be justified as comprehensively rational, see Diver, Policymaking Paradigms in Administrative Law, 95 HARV. L. REV. 393, 411-13 (1981), when they may in fact have been based on quite different considerations, self-interested or otherwise. Courts have, however, maintained a veil between appearance and reality by refusing to force disclosure of off-the-record negotiations and political discussions that influence regulatory decisionmaking in rulemaking, thereby limiting the rulemaking record to data and analytical studies. See Sierra Club v. Costle, 657 F.2d 298, 396-97 (D.C. Cir. 1981); Action for Children's Television v. FCC, 564 F.2d 458, 477 (D.C. Cir. 1977).

Finally, when courts proceed as if the participants in the political process and the litigants before them are bearers of public values, as this Article and my reading of Ely, The Irrepressible Myth of Erie, supra note 43, suggests that they should, they face a dilemma. To the extent that courts-whether they are considering principles of constitutional or of administrative law -themselves seek to determine whether a particular controverted measure is in fact justified by the relevant public values, they override the civic processes of debate and decision in other fora which generally offer superior opportunities for the participation and education of citizens. See Michelman, supra note 18, at 506-10.

To the extent that judges assert the need for public value justifications but in fact exhibit deference to decisions of other fora-decisions reflecting pressures and considerations that are in some measure self-interested-they risk generating cynicism. Although they may seek to avoid these problems by 
of why regulatory law emerges and assumes the form that it does. The terms of the resulting statutes and regulations set bounds, but the deals conception is not an adequate norm to guide the courts in their work.

\section{Regulation Based on Rights}

Under an entitlement conception, the extent and content of regulation are defined by the respective rights of regulated firms ("defendants") and regulatory beneficiaries ("plaintiffs"). ${ }^{70}$ The entitlement conception views regulation as the common law's successor in defining and securing personal rights. By creating zones of personal thought and action protected against outside intrusion, such rights make individual choice possible and are thus a necessary foundation of any liberal jurisprudence, even the minimalist version represented by the deals thesis. ${ }^{71}$ The conditions of industrialization, however, sapped the ability of the common law to protect rights effectively, necessitating the creation of administrative authorities to assume this task and secure rights to honest commercial dealing, a healthy environment, and so on.

This account promises a way of reconciling regulation with the liberal principles of neutrality and avoidance of coerced wealth transfers. If the common law, regarded as a system of boundary and transactional rules, successfully promotes decentralized pursuit of plural values, then a regulatory version of that system may also pass muster. ${ }^{72}$ But this promise is at best a limited one.

Some regulatory programs, such as those dealing with race and sex discrimination, can perhaps be accounted for in terms of entitlement conceptions. ${ }^{73}$ Organic statutes, by limiting regulatory agencies' powers, may

adopting a Landes-Posner approach, they not only abandon for themselves a conception of society based on other than self-regarding considerations, but encourage others to do so as well.

70. See Stewart \& Sunstein, supra note 3, at 1271-72. Administrative agencies might be viewed as "dominant protective associations" to whom citizens have delegated the enforcement of their rights because conditions of urban industrialism have made individual enforcement too costly or clumsy. See R. NOZICK, ANARCHY, STATE, AND UTOPIA 15-22, 78-84 (1974).

The original conception of administrative agencies was that they would function as a sort of specialized court to redefine and enforce entitlements under industrial conditions. See J. DiCKINSON, ADMINISTRATIVE JUSTICE AND THE SUPREMAGY OF LAW 10-13 (1927); B. MITNICK, THE POLITICAL ECONOMY OF REGULATION 97 (1980).

71. See C. FRJED, RIGHT AND WRONG, supra note 14, at 100-04.

72. The internal logic of an entitlement system might discipline the ingut of interest group pressure in such a way as to ensure a regulatory scheme that worked itself pure and satisfied the principle of neutrality. Hayek portrays common law adjudication as a process that accomplishes this alchemical transformation. See 1 F. HAYER, LAW, LEGISLATION, AND LIBERTY 118-22 (1973). He would, however, deny that regulatory legislation and administration could achieve a similar transformation. See id. at 97-98.

73. With the development of antidiscrimination law with respect to race, gender, age, and handicaps, however, it has become increasingly clear that neither violations nor remedies can be defined in terms of individual entitlements. See Fiss, Groups and the Equal Protection Clause, 5 PHIL. \& PUB. AFF. 107 (1976). The effort to integrate a school system or redirect the employment practices of a 
give rise to defensive rights by regulated firms, and statutes sometimes confer regulatory protection in specific terms that can support affirmative rights on behalf of regulatory beneficiaries. In a pervasively industrialized and regulated society, however, most regulatory programs and choices cannot be defined or implemented in terms of juridical rights. Such rights are generated by stable, general, categorical and determinate rules and principles. ${ }^{74}$ The probabilistic, collective-good nature of the benefits provided by regulation and the variability in economic and geographic conditions prevent the development of such rules and principles. Regulation must, under conditions of relatively rapidly changing social and economic conditions, influence the behavior of many differently situated actors in order to provide, in the face of limited resources, protection to many differently situated regulatory beneficiaries. This task of management cannot be reduced to a system of juridical entitlements.

The potential demand for regulatory protection will almost always outstrip the enforcement and compliance resources that society is willing to provide for such protection. A system of regulation based on entitlements would present courts with the Herculean task of "rationing" entitlements among claimants all of whom can plausibly claim protection.

The problem, however, is not simply a remedial one. Because regulatory benefits are collective and probabilistic, determination of the appropriate content of regulatory protection is necessarily contingent and arbitrary-characteristics incompatible with a system of rights. ${ }^{75}$ In regulating

large enterprise has come to resemble the complex allocative management tasks involved in regulation. See Chayes, The Role of the Judge in Public Law Litigation, 89 HARV. L. REV. 1281 (1976).

74. See Stewart \& Sunstein, supra note 3, at 1242.

75. Richard Epstein has argued that the content of common law obligations and privileges can be derived from a deontological system of moral rights and duties, and that "utilitarian" considerations play a role only at the remedial stage. See Epstein, Nuisance Law: Corrective Justice and Its Utilitarian Constraints, 8 J. LEGAL STUD. 49, $78-79$ (1979); Epstein, The Principles of Environmental Protection: The Case of Superfund, 2 CATO J. 9 (1982). Under such an approach, administrative agencies might be regarded simply as utilitarian remedial devices to elaborate and enforce standards of conduct whose content could be determined by common-law-like juridical conceptions of entitlement. This position is, however, untenable, for the reasons developed in the text.

The common law developed in an era in which the interactions among individuals were less complex. Technology was far less developed. Moreover, scientific knowledge concerning the more subtle or complex health and environmental effects of activities was primitive. In these circumstances, satisfactory adjustments could often be achieved through relatively clear-cut, widely-applicable "boundary crossing" rules, such as those of trespass. Even where a more particularized assessment was necessary-as in many cases of nuisance-the situations involved were relatively limited and simple.

Today, the legal system must cope with thousands of different activities and tens of thousands of different chemicals that pose different, difficult to identify, risks to health and the environment. Because of limits in knowledge and a variety of practical difficulties, it is not feasible to establish a universal risk exposure standard-a modern-day equivalent of a trespass rule-that could serve as the basis for regulating all substances and activities generating such risks. (Even if one could be established, its precise content would be arbitrary.) Accordingly, regulation must proceed through thousands of different standards or other measures to cope with each of these sources of risk.

Analogous difficulties affect common law efforts to deal with problems such as pollution under contemporary conditions. Damages-the classic common law remedy for violations of rights-are 
oil exploration and production on outer continental shelf lands, for example, the government must decide which lands should be developed under what environmental safeguards. An initial problem is defining the class or classes of persons with rights to regulatory protection: Those that fish affected waters? Coastal property owners? Users of public beaches? Owners of tourist businesses? A second problem is the appropriate level of protection. If, as is typically the case, society is not prepared to eliminate all risk of harm to all potential beneficiaries, how should the content of their respective entitlements be defined? How does one choose, on entitlement grounds, between a measure that yields a $.0005 \%$ annual probability of a major spill and one that yields a $.0003 \%$ probability? Not only the expected level of risk but also its distribution affect the calculus. Decisions as to the timing, location, and conduct of regulated activities will create different patterns of risk that expose different individuals to different threats. Should we permit development of lands near the shore, threatening shore activities, or lands that are further offshore but closer to rich fish-spawning grounds like the Georges Bank? The problem of arbitrariness in the definition of rights is pervasive. ${ }^{76}$ Even if a set of non-arbitrary entitlements to regulatory protection could initially be established, the content and structure of such entitlements would have to be constantly adjusted in response to changing economic and social conditions in order to maintain the specific relations that rights require. ${ }^{77}$ Such a kaleidoscopically shifting set of arrangements can hardly qualify as a system of rights.

often not an appropriate or workable remedy because harms are collective and often consist of individually small, but, in the aggregate, potentially significant risks of ecological or health harm at some uncertain point in the future. In these circumstances, injunctive remedies are often necessary to provide effective relief. Injunctive remedies, however, present most or all of the difficulties discussed in the text with respect to administrative regulation.

76. The example of environmental regulation used in the text consists of general regulations specifying permitted conduct. The essential point would be the same when regulation takes the form of case-by-case screening of particular products or facilitics in accordance with general criteria such as "unreasonable risk." This type of regulation occurs in the licensing of new drugs or the siting of power plants.

Similar problems arise in broadcast regulation in the context of asserted rights to diverse programming. See infra pp. 1581-82. For a discussion of the concept of program diversity, see $R$. CaSS, REVOLUTION IN THE WASTELAND, VALUE AND DIVERSITY IN TELEVISION (1981); H. LEVIN, FACT AND FANCY IN TELEVISION REGULATION (1980).

The fact that the content of regulatory programs cannot be defined by reference to entitlements does not exclude the possibility that regulatory requirements whose content is determined on other grounds might be enforceable as rights through, for example, a citizen suit provision. See 42 U.S.C. $\S 7604$ (1982) (Clean Air Act citizen suits). Nor does it exclude the possibility that one might have a right, in the sense of a moral claim, to freedom from certain types of environmental harms. Such a claim might be grounded on various moral theories, including deontological, utilitarian, or wealth-maximizing ones. The burden of the argument here is that such a claim could not be realized in the form of relatively stable, general, categorical, and determinate juridical rules and principles.

77. In contrast to command and control regulation, which mandates specific conduct by those regulated, the combination of contract, property, and tort principles in the common law may be regarded as a set of transactional ground rules allowing private actors considerable flexibility in mutually ordering their affairs. Such a framework could better accommodate change without constant, far- 
These difficulties in constructing a system of entitlements on behalf of "plaintiff" regulatory beneficiaries are mirrored by parallel difficulties in defining the correlative rights of the regulated "defendants." The definition of such rights is inevitably arbitrary. In a pervasively regulated economy, common law property rights can no longer serve as a yardstick to mark the permissible limits of regulatory intervention. Nor are statutes likely to fix the precise bounds and contents of agency regulatory power.

How much in the way of less popular, and therefore less profitable, local and community service broadcaster programming may the FCC require? What are the limits of the Interior Department's authority to require OCS rig operators to spend money to reduce the risk of oil spills? These questions must be answered through a complex allocational process that weighs the benefits and costs of various alternatives and the agency resources available to implement them. In order to prevent competitive distortions and husband scarce compliance resources, an agency must consider the distribution of regulatory burdens among different firms. Moreover, these firms are subject to other regulations, administered by other agencies. The ultimate task of administrative management must thus cope simultaneously with at least four interactive factors: limited agency resources for discharging multiple tasks; different potential beneficiaries; different regulated actors who compete with one another to a greater or lesser degree; and limited societal resources for reducing multiple risks. Any one of these dimensions alone could justify the label "polycentric." In these circumstances, the notion of a juridical right to environmental quality or broadcast diversity is simply a non-starter.

This conclusion has an institutional aspect. The characteristics of our courts-case-by-case resolution by an impartial judge of disputes, initiated by adversary litigants, on the basis of the evidence and claims which they present-is equipped for deciding bipolar cases by reference to entitlements. But these various characteristics make it unlikely that courts can successfully carry out the allocational tasks involved in regulatory management. ${ }^{78}$

reaching revision of the legal principles themselves.

78. The institutional limitations of courts are reflected in efforts to apply adjudicatory procedures to regulatory tasks such as broadcast license allocation, see Johnston Broadcasting Co. v. FCC, 175 F.2d 351, 358 (D.C. Cir. 1949), or power plant siting, see Scenic Hudson Preservation Conf. v. FPC, 453 F.2d 463 (2d Cir. 1971), cert. denied, 407 U.S. 926 (1972). Experience has shown that procedures developed to decide disputes over entitlements are ill suited for the quite different type of decisions that must be made in regulatory administration. See Reich, The Law of the Planned Society, 75 YALE L.J. 1227 (1966). The dysfunctional consequences of efforts to reduce "mass justice" welfare administration to a juridical system of rights are discussed in J. MASHAW, supra note 3; P. NONET, ADMINISTRATIVE JUSTICE (1969). 


\section{Regulation Based on Wealth Maximization}

Wealth maximization provides another possible foundation for regulatory law choices in a liberal state. The goal of wealth maximization is to produce the greatest output of goods, services, and amenities, as measured by the aggregate economic value that individuals place on such commodities. ${ }^{79}$

Such a goal may seem to provide an appropriate framework for the complex allocational tasks that modern regulation typically involves-tasks that cannot be reduced to a question of entitlement. Wealth maximization also appears at first glance to reconcile regulation with the public-interest and neutrality tenets of liberalism. In the current era of heightened regulatory turmoil, the apparent neutrality of the wealthmaximizing principle is a great attraction. It promises conscientious and perplexed regulators an even-handed, welfare-enhancing solution to controversial policy choices. ${ }^{80}$ Wealth-maximization seems neutral because it defines value as an aggregate function of each individual's preferences; it does not single out the preferences of some particular individuals or groups and give them controlling weight. In addition, regulation designed to achieve output maximization cannot readily be condemned as a system of coerced wealth transfers; output maximization is a collective measure of welfare in which the interests of all citizens "count."81

These features of the wealth-maximizing principle-together with its power as a tool for assessing the performance of regulatory programs $^{82}$ - help explain its considerable appeal for policy analysts and reg-

79. The economic value which an individual places on a commodity, opportunity, or amenity may be defined either in terms of his bid price, or willingness to pay to enjoy it (which assumes that he does not have a prior entitlement to it), or in terms of his asking price, or the price that he would accept to part with it (which assumes that he does have a prior entitlement to it). This distinction, which has potentially significant distributional and allocational implications, underlines the necessity of some background set of entitlements upon which the efficiency calculus can rest. See Kennedy, Cost-Benefit Analysis of Entitlement Programs: A Critique, 33 STAN. L. REV. 387, 401-21 (1981). Another set of difficulties arises from the selection of rules for aggregating or summing the economic values placed by individuals on outcomes. See A. SEN, COLLECTIVE CHOICE AND INDIVIDUAL WEL FARE (1970). Additional problems are created if the overall distribution of benefits must satisfy some distributional requirement or constraint. See R. TRESCH, PUBLIC FinANCE: A NORMATIVE THEORY 541-55 (1981).

80. See Remarks of Christopher DeMuth, Associate Director of Office of Management and Budget, in 13 ENV'T REP. (BNA) 1574, 1574-75 (Jan. 14, 1983).

No one supposes that cost-benefit analysis determines regulatory outcomes even in those agencies that use it most extensively. Political and bureaucratic factors are of great importance. See B. ACKERMAN, S. ROSE-ACKERMAN, J. SAWYER, \& D. HENDERSON, THE UNCERTAIN SEARCH FOR ENVIRONMENTAL QUALITY 165-223 (1974). But such analysis, if widely employed and accepted as legitimate, is likely to have a pervasive and cumulatively significant role in shaping the terms of debate and decision.

81. Preferences are, however, weighted in proportion to wealth, a circumstance that may create a danger that regulatory policies based on wealth-maximization will violate the liberal tenets.

82. See S. BREYER, supra note 1, at 191-96. 
ulatory administrators. ${ }^{83}$ But the principle raises a large number of hotlydebated methodological and normative issues. ${ }^{84}$ Because many of these issues have been fully canvassed elsewhere, ${ }^{85}$ the discussion here focuses on three special difficulties in reconciling wealth maximization with liberal principles.

One difficulty in reconciling wealth maximization with liberal principles is that all regulation that is not wholly paternalistic ${ }^{88}$ imposes controls on one person's behavior in order to advance the welfare of others. Because it is normally infeasible to charge each beneficiary with a share of the costs of providing a collective good that is proportionate to his share of the benefits, asymmetry in the distribution of benefits and burdens is inevitable. Such asymmetry is particularly troubling when some citizens are net losers. Assume, for example, that many citizens have a strong preference for maintaining pristine wetlands; the economic benefits of restricting wetlands development (as measured, for example, by the summed willingness-to-pay of wetlands lovers) exceed the opportunity costs of such restrictions. Regulations are then adopted to restrict wetland development. Are liberal principles being violated because wetland owners are coerced in order to promote others' values? ${ }^{87}$

There are at least three responses to this situation. First, each regulatory measure may be required to pass a test of Pareto superiority: It must make some citizens better off while making none worse off. In most cases, this test would require the payment of compensation to losers, an administratively difficult task whose costs might often exceed the net welfare gain

83. See, e.g., Exec. Order No. 12,291, 3 C.F.R. 127 (1981) (mandating cost-benefit analysis by federal regulatory agencies); E. STOKEY \& R. ZECKHAUSER, A PRIMER FOR POLICY ANALYSIS 134-58 (1978) (evaluating cost-benefit analysis).

84. For example, application of the wealth-maximization principle requires a background set of entitlement rules to determine the starting point from which the gains and losses generated by proposed regulation are to be defined and measured. In a heavily regulated economy, however, neither the common law nor any other judicial system of property rights provides a workable yardstick. Regulation arose in large part because of the remedial limitations of the common law in dealing with the widespread spillovers and other market failures associated with industrial market economies. Consider, for example, pollution that creates widespread disamenity and risk of future health harm. Are we to suppose, in constructing the baseline, that because the common law (let us assume) prevents such harms de jure, receptors therefore have an entitlement to be free of pollution or do we assume that polluters have an entitlement to pollute because severe remedial problems result in a de facto tolerance of such pollution by the common law regime? At the same time, the normative claim of the regulatory status quo to serve as a starting point is questionable. What starting point should be selected? See Kennedy, supra note 79, at 427-29, for further discussion of this and other methodological problems in determining the common law baselines against which regulatory interventions are to be measured.

85. See, e.g., Symposium on Efficiency as a Legal Concern, 8 HOFSTRA L. REV. 485 (1980); A Response to the Efficiency Symposium, 8 HOFSTRA L. REV. 811 (1980).

86. For a brief discussion of the role of paternalism in regulation, see supra note 12.

87. Assume for purposes of discussion that the restriction does not violate any rights of the owners and is not justified on the ground that it would prevent violations of rights caused by wetlands development. 
from the regulation. Second, liberal principles might be satisfied whenever both costs and benefits are widely distributed and there is a substantial margin of net benefit. An example might be regulatory controls on electric power plant emissions that produced substantial, widespread health benefits at low cost. Third, a Pareto superiority principle might be applied at a wholesale rather than a retail level: The public interest tenet of liberalism would be violated only when an entire series of regulatory measures has imposed net losses on some actors. ${ }^{88}$

A second difficulty in reconciling wealth maximization with liberal tenets is the problem of what, in an economic perspective, may be characterized as "moralisms" or "external preferences"-preferences that individuals have regarding the behavior of others. ${ }^{89}$ It seems plain that regulation in the liberal state cannot be based on negative preferences-on the view that someone else's behavior is inherently unworthy or disgusting and ought therefore to be stopped. Banning X-rated cable programming on the ground that it is corrupting, for example, violates the neutrality principle. ${ }^{90}$ It follows that pollution or wetlands development cannot be prohibited because citizens believe such activity to be inherently evil, regardless of any material effects it might have.

Positive external preferences, however, create a more difficult problem. Suppose that I favor the broadcast of Shakespeare plays on television not simply because I enjoy them but because I believe that others would be better off if they watched and came to appreciate Shakespeare. Would

88. See Polinsky, Probabilistic Compensation Criteria, 86 Q.J. ECON. 407, 412-18 (1972); Posner, The Ethical and Political Basis of the Efficiency Norm in Common Law Adjudication, 8 HoFSTRA L. REV. 487 (1980). For discussion and criticism of this approach, see Bebchuk, The Pursuit of a Bigger Pie: Can Everyone Expect a Bigger Slice?, 8 HOFSTRA L. REV. 671 (1980). To implement such an approach, one would presumably have to rely on wholesale institutional arrangements likely to produce, in the aggregate, widespread sharing of the wealth increases created by regulation, rather than a regulation-by-regulation accounting. But how would the efficacy of such arrangements be tested and assured? See Michelman, Property, Utility, and Fairness: Comments on the Ethical Foundations of "Just Compensation" Law, 80 HARV. L. REV. 1165, 1176-81 (1967). Elements of such a strategy are outlined in Karst, The Supreme Court, 1976 Term-Foreword: Equal Citizenship Under the Fourteenth Amendment, 91 HARV. L. REV. 70, 89-94 (1977).

89. See Baker, Counting Preferences in Collective Choice Situations, 25 UCLA L. REV. 381 (1978).

90. The government might, however, respond to this charge by denying responsibility for the external preferences that it enforces, just as it generally denies responsibility for the content of citizens' preferences in regulation based on wealth maximization. If enforcing private citizens' preferences for clean air does not violate neutrality, why does enforcement of their preference for decorous behavior by others? Regulation to control automobile air pollution does not, however, entail condemnation of the preferences of those who care little for clean air and would prefer faster or more fuel efficient cars rather than cleaner ones. (Such regulation may make it more difficult or costly for such persons to satisfy their preferences, but such opportunity costs are inevitable.) Such condemnation, however, is the inevitable and explicit purpose of the movie ban. Cf. Stewart, supra note 6, at 1739 (doctrines governing standing to secure judicial review reflect liberal view that government should advance material interests of citizens but may not enforce their ideological views against others). 
regulatory policies designed to implement preferences such as mine violate liberal tenets?

This issue merges with the question of non-commodity values. Such values present a third difficulty in reconciling regulation with liberal principles. As explained more fully in the following section, a liberal society should seek to enhance the capacities and opportunities of citizens to examine critically their existing values, and to expand and enrich the available conceptions of the good. This objective requires nurture of the noncommodity values of aspiration, mutuality, civic virtue, and diversity characteristic of the American associational tradition. Such a conception of liberalism rejects a model of choice-a model that is almost inevitable in a wealth-maximizing approach-in which persons make a series of discrete commodity consumption decisions with a view to maximizing, within budget constraints, satisfaction of their current subjective preference sets.

The incompatibility between wealth maximization and non-commodity values is made clear by the methodologies devised to measure the economic value to individuals of collective goods such as environmental quality or more diverse television programming. ${ }^{91}$ One technique is to identify and measure market variables that reflect the value that individuals place on a collective good. If, for example, individuals value clean air, they would presumably pay higher prices for housing in areas with clean air. If they dislike polluted work places, they are likely to demand higher wages for working in such places. By correlating variations in property values or wages with variations in air pollution, one can attempt to derive the value that individuals place on clean air. ${ }^{92}$ Similarly, one may seek to derive the value that television viewers attach to program diversity from the amounts they pay for cable service. ${ }^{83}$

Because this approach has several important theoretical and practical limitations, ${ }^{94}$ economists have also devised survey techniques that use in-

91. See Cost-Beneft ANalysis \& Water POllution POLicy (H. Peskin \& E. Seskin eds. 1975); A. FERGUSON \& E. LEVEEN, THE BENEFITS OF HEALTH AND SAFETY REGULATION (1981); A. FREEMAN, THE BENEFITS OF ENVIRONMENTAL IMPROVEMENT (1979); H. LEVIN, supra note 76. Another approach is to measure the direct cost savings (such as reduced medical costs due to healthier air) attributable to regulatory benefits; this would presumably be less than willingness to pay for such benefits, but would establish a lower bound. See L. LAVE \& E. SESKIN, AIR POLLUTION AND HUMAN HEALTH (1977).

92. See, e.g., Bayless, Measuring the Benefits of Air Quality Improvements: A Hedonic Salary Approach, 9 J. ENVTL. ECON. \& MGMT. 81 (1982). Harrison \& Rubinfeld, Hedonic Housing Prices and the Demand for Clean Air, 5 J. ENVTL. ECON. \& MGMT. 81 (1978).

93. See H. LEVIN, supra note 76 .

94. The decisions being measured by the market may themselves be infected by "market failures" such as inadequate information; individuals, for example, may be ignorant of adverse health effects associated with air pollution. It may be difficult to isolate the impact of one variable-such as air pollution-from that of all of the other variables that affect wage rates or property values. Or there may be no close market analogue or measure of the benefit which a proposed regulation seeks to provide. For an example of the ingenuity to which economists may be driven in order to cope with 
terviews or simulations to elicit the economic value that an individual places on a collective benefit. ${ }^{95}$ But these techniques also have drawbacks, such as the difficulties subjects face in assimilating information and making decisions with which they have no experience.

All of these techniques attempt to isolate an individual's valuation of a collective good from the values or actions that others might hold or take with respect to such a good. In order to screen out strategic behavior and permit a mathematically tractable summing of values, they seek to elicit the individual's willingness to pay for the benefits that he receives from a collective good, considered as an individual commodity chosen and consumed by him alone, with a view to maximizing the sum of individual demands. ${ }^{98}$ This approach to choice excludes important non-commodity values discussed in the following section. Because regulation based solely on wealth maximization excludes these values, it violates liberal principles by imposing on citizens a particular and limited conception of the good.

Even if these three theoretical problems were disregarded, the wealthmaximizing principle is a dubious foundation for administrative law. Courts are institutionally ill-suited to assess the likely consequences of regulatory initiatives or to identify their associated costs and benefits. ${ }^{97}$ The problem of benefit measurement is particularly acute because forensic processes are especially ill-suited for identifying and summing preferences. ${ }^{98}$

Consider, for example, judicial review of the question whether the FCC should impose regulatory restrictions on subscription cable television services in order to protect advertiser-supported, over-the-air broadcasting. Will such restrictions increase wealth? On the one hand, there is a "market failure" in advertiser-supported television: It largely fails to respond to differences in the intensity of preferences that viewers have for various programs-a defect that subscription television would cure. On the other hand, subscription television also suffers from a market failure attributable to the fact that the marginal or incremental cost of supplying addi-

such difficulties, see J. Kalt, The Costs and Benefits of Federal Regulation of Coal Stripmining (Discussion Paper Series, Kennedy School of Government, Harvard Univ., No. E-82-08).

95. See J. GREEN \& J. LAFFonT, INCENTIVES IN PUBLIC DECISION-MAKING 3-78 (1978); Brookshire, Thayer, Schulze, \& d'Arge, Valuing Public Gocds: A Comparison of Survey and Hedonic Approaches, 72 AM. ECON. REV. 165 (1982).

.96. Surveys of individuals' willingness to pay have been used to value the protection of remote recreational areas, see Rowe, d'Arge \& Brookshire, An Experiment in the Value of Visibility, $7 \mathrm{~J}$. ENVTL. ECON. \& MGMT. 1, 1-19 (1980), the air quality in the Los Angeles metropolitan area, see Brookshire, Experiment in Valuing Public Goods, in ADVANCES IN APPLIED MICROECONOMICS (V. Smith ed. 1980), and the demand for public television, see Bohm, Estimating Demand for Public Goods: An Experiment, 3 EUR. ECON. REV. 111-30 (1972).

97. See Stewart \& Sunstein, supra note 3, at 1275-78.

98. This is one of the underlying reasons why adjudicatory procedures are, as already noted, poorly suited for many regulatory decisions. See supra note 78 . 
tional consumers approaches zero. Economic logic dictates that viewers be charged a price equal to marginal costs, but this will not enable the company to recoup the overhead costs of establishing and running the system. Charging a price based on average cost to cover these expenses will exclude some viewers who would subscribe if they were charged a price based on the incremental costs of serving them. This will result in a loss of potential consumer welfare. ${ }^{98}$ Will a mix of subscription cable and advertiser-supported television be better than either alone? What mix? ${ }^{100}$

Such a decision, however, is relatively straightforward in comparison to many environmental regulatory and resource management choices. Consider the decision whether to permit oil development of the outer continental shelf off northern California. Given the complexity and uncertainty of the economic, engineering, geological, meteorological, and ecological questions involved in determining the risks of spills, and given the difficulties in identifying and summing individuals' preferences for various probabilistic environmental benefits, how can a court determine which decision will advance economic welfare? ${ }^{101}$

Courts' institutional shortcomings are reflected in their refusal to apply a common economic yardstick to regulatory benefits and costs. Courts instead tend to equate economic productivity with the unregulated market, in juxtaposition to various other values, such as environmental or health protection, which are to be advanced by regulation. ${ }^{102}$ In policing the

99. For a general discussion of the problem of pricing commodities whose production is characterized by declining marginal costs, see S. BREYER \& R. STEWART, ADMINISTRATIVE LAW AND REGULATORY POLICY $445-50$ (1978). For specific discussion in the context of broadcasting, see R. NOLL, M. PECK \& J. MCGOWAN, ECONOMIC ASPECTS OF TELEVISION REGULATION (1973).

100. At first glance, more channels might seem preferable because greater competition enhances consumer welfare. But there are economies of scale in television production and distribution which may be impaired by an increase in number of channels, leading to a potential loss in consumer welfare. In such circumstances, all consumers might be better off if they jointly agreed to sacrifice their freedom to "shop" for diverse programs by agreeing to watch a relatively small number of channels in order to realize the resulting scale economies, that is, in order to see better shows which tend to be more expensive to produce. But transaction costs would prevent the negotiation of any such agreement. An administrative agency can impose the equivalent of such an agreement by restricting the number of channels. But, unlike a system of voluntary agreement (if it were available), there is no reliable way by which the administrator can determine whether such a regulation would enhance consumer welfare or whether the restriction of competition and choice would involve losses exceeding whatever gains might be achieved by realizing scale economies.

101. Administrative agencies have a number of institutional advantages over courts in dealing with such issues. First, agencies are better equipped in terms of resources and procedures to identify, obtain, and evaluate relevant data and analysis. Second, insofar as the political system operates as a mechanism to register preferences for collective goods, agencies are more responsive to that mechanism. Third, they can coordinate regulatory decisions that courts deal with in isolation. The consequences and desirability of a particular regulatory proposal can rarely be judged in isolation from other proposals. For example, the need to develop oil reserves off northern California and the acceptability of the risks associated with such development cannot be judged in isolation from a consideration of the other sites at which oil might be developed. See Note, Sales of Public Land: A Problem in Legislative and Judicial Control of Administrative Action, 96 HARV. L. REV. 927 (1983).

102. See Stewart and Sunstein, supra note 3, at 1241-45. 
boundary separating the unregulated market and regulatory public values, reviewing courts generally require agencies to identify and discuss the expenditures that regulated firms must make and the competitive dislocations that they will suffer as a result of regulation. Agencies must also attempt to identify and evaluate the benefits that the regulation will provide; these benefits are generally defined in non-economic terms, such as reduced illness. ${ }^{103}$

There are major flaws in this approach from the viewpoint of wealth maximization. On the one hand, compliance outlays and competitive dislocations are a poor measure of the economic costs to society of regulation. ${ }^{304}$ On the other, an economically rational calibration of costs and benefits requires that the benefits of regulation be reduced to economic terms, by summing the commodity values that individuals would place on those benefits. This approach, as already noted, errs by ignoring important non-commodity objectives of regulation. ${ }^{108}$ But the courts, for institutionally understandable reasons, have committed the opposite error of ignoring the economic or commodity dimensions of regulatory benefits. As a result, there has not been adequate consideration of the respective roles that commodity and non-commodity objectives should enjoy in regulatory policy.

\section{Non-Commodity Values}

This section outlines a theory of non-commodity values which addresses shortcomings in the various conceptions of regulatory law examined in previous sections.

Aspiration, diversity, mutuality, and civic virtue are integral to the liberal ideal that individuals choose and realize their own conception of the good. They enable individuals to appraise critically their existing preferences and to experience and test different conceptions of the good. Noncommodity values also encourage individual involvement in necessarily collective determinations of social and economic conditions. These values, historically nurtured in the decentralized, associational tradition of American liberalism, must be addressed by the regulatory programs of a developed national economy. To disregard such values and base regulation exclusively on wealth-maximizing commodity values would violate liberal principles by dictating to citizens a particular conception of the good.

103. See, e.g., American Textile Mfrs. Inst. v. Donovan, 452 U.S. 490 (1981); Industrial Union Dep't v. American Petroleum Inst., 448 U.S. 607 (1980); Portland Cement Ass'n v. Ruckelshaus, 486 F.2d 375 (D.C. Cir. 1973), cert. denied, 417 U.S. 921 (1974).

104. See Stewart, supra note 38, at 1259-60, 1288-95.

105. See supra p. 1564. 


\section{A. Ingredients of a More Ample Liberalism}

As stated in the introduction to this Article, liberalism has often been caricatured as a myopic social and political creed that celebrates subjectivity, egoism, and commodity values. The elements of truth in that attack stirred concern among nineteenth-century liberals, most notably John Stuart Mill. In On Liberty, Mill argued for limits on social and governmental authority in order to liberate individuals from society's homogenizing tendencies. ${ }^{106}$ But many of Mill's other writings reflect the conviction that a purely private conception of liberty could impoverish individual experience and capacity for self-realization. ${ }^{107}$ These concerns have been revived by contemporary scholars who criticize liberal conceptions of law and society and the law and economics movement. ${ }^{108}$ There is today fresh interest in developing a more "ample liberalism" that recognizes the need to develop in individuals a critical capability with respect to their preferences. ${ }^{109}$

Such a capability is central to a Pelagian conception of liberalism that affirms the supreme value of individual self-determination, ${ }_{2}^{10}$ for without such a critical capacity one can hardly be said to choose one's own ends. This conception of liberalism also requires a substantial diversity in the conceptions of the good accessible to individuals. Such diversity depends upon heterogeneous social, intellectual, and physical environments. Voluntarism also implies opportunity for participation in the collective determination of social and physical environments that shape both the ends available to individuals and the means to realize them. These considerations suggest the following principles as elements of a more ample conception of

106. I have nominated Mill as a representative thinker because he was so fully sensitive to the internal tensions in any conception of liberalism that was responsive both to the richness of human experience and aspiration and to the exigencies of modern government. Matthew Arnold and T.H. Green shared similar concerns. See M. ARNOLD, CULTURE AND ANARCHY (1869); E. ALEXANDER, MATTHEW ARNOLD AND J.S. Mill (1965); M. RICHTER, THE POLITICS OF CONSCIENCE: T.H. GREEN AND HIS AGE (1964); cf. K. POLANYI, THE GREAT TRANSFORMATION 255-56 (1973) (contemporary task to maintain values of "moral freedom and independence of mind" fostered by nineteenthcentury economic and legal arrangements in post-market era).

107. See, e.g., J. MILL, ON LIBERTY 94-98 (Everyman ed. 1940) (1st ed. London 1859) (collective and individual development depends on critical self-examination of prevailing beliefs and values); Mill, Representative Government, in THREE ESSAYS 167-68, 170, 197 (R. Wollheim ed. 1975) (worth of government measured by moral and intellectual development of citizens).

108. See, e.g., Kelman, Choice and Utility, 1979 WIS. L. REV. 769; Kelman, Consumption Theory, Production Theory, and Ideology in the Coase Theorem, 52 S. CAL. L. REV. 669 (1979); Kennedy, supra note 79.

109. See, e.g., Michelman, Political Markets and Community Self-Determination: Competing Judicial Models of Local Government Legitimacy, 53 IND. L.J. 145 (1977-78); Unger, supra note 2 (ideal of "superliberalism").

110. See B. ACKERMAN, supra note 8; J. RAWLS, supra note 9; M. SANDEL, LIBERALISM AND THE LIMITS OF JUSTICE (1982); Unger, supra note 2. 
liberalism that would have important implications for regulatory jurisprudence:

Aspiration-The social and physical environment should, consistent with liberal principles, equip and encourage individuals to examine critically their existing conceptions of the good. It should also provide opportunities for individuals to develop and pursue those conceptions which, on reflection, appear to them more worthy and fulfilling. We may term this the value of aspiration.

Diversity-A diversity of economic, cultural, and physical environments should be fostered. A homogeneous society will not provide a setting in which an individual can readily discover and test divergent conceptions of the good as part of the process of reflective self-development that the principle of aspiration implies. ${ }^{111}$ This diversity can in some respects be promoted by limiting the power of government to dictate or shape individual preferences, but it may in other respects require collective action. Education is one example; environmental regulation is another.

Mutuality - The foundation of a liberal society is respect by each individual of every other's right to pursue his own conception of the good. But respect also implies concern for the adequacy of others' opportunities to pursue their conceptions of the good. ${ }^{112}$ Prima facie, each citizen should be afforded the material and other ingredients of such opportunities in order to advance the liberal ideal of society as a joint enterprise for pursuit of different forms of excellence. This goal may require that citizens be provided not only a minimum income or housing, but also access to noncommodity opportunities that may be created by regulation.

Givic virtue-Liberalism should invite individuals to take an active role in the direction of collective affairs through participation in voluntary associations and political activity. Such participation can nurture the sentiment of mutuality and diversify individuals' conceptions of the good to include associational and communal goals. ${ }^{113}$

The decentralized, associational character of American liberalism did much to promote these four non-commodity values. Decentralization, combined with geographical, economic, ethnic, and cultural variety, generated substantial diversity. Civic virtue was promoted by conditions favoring participation in voluntary associations and a variety of local governmental bodies. Mutuality and aspiration were fostered by church groups,

111. See Stewart, The Development of Administrative and Quasi-Constitutional Law in Judicial Review of Environmental Decisionmaking: Lessons from the Clean Air Act, 62 IOWA L. REV. 713, 750-54 (1977).

112. See R. DWORKIN, TAKING RIGHTS SERIOUSLY 273 (1977); M. SANDEL, supra note 110, at 61.

113. See J. MILL, Representative Government, in THREE ESSAYS, supra note 107, at 167, 181-82, $186,190,197-98$. 
farmers' cooperatives, and workers' associations. Because these values are, for reasons already explained, disregarded by the principle of commoditybased wealth-maximization, we may appropriately term them non-commodity values.

In excluding non-commodity values, wealth-maximization ignores the intimate and inevitable interdependencies involved in collective choices. ${ }^{114}$ It also ignores the powerful effects that such choices exert on individual preferences when they determine basic features of the physical and social environment. ${ }^{115}$ By denying that non-commodity values are an appropriate ground of individual and social choices, wealth maximization denies important and relevant conceptions of the good. Wealth maximization is not-contrary to initial appearances-consistent with liberal principles. It is instead a form of tyranny that would impose on individuals a partial, sectarian conception of the good. Liberal principles demand that regulation cultivate non-commodity values.

\section{B. Non-Commodity Regulation and Liberal Principles}

Expanding regulatory objectives to include non-commodity values raises three related questions. Is regulatory promotion of non-commodity values itself consistent with liberal principles? What is the appropriate role of

114. The wealth-maximizing approach deliberately seeks to exclude the inevitable interdependencies in collective-good decisions. If I am asked how much I alone would pay to reduce air pollution over the Grand Canyon or toxic wastes in drinking water, my evaluation cannot incorporate collective considerations. These considerations include the appropriate procedures for deciding issues involving indivisibilities as well as such questions as whether society should collectively encourage geographically diverse levels of environmental quality and economic development, or whether it should aspire to higher levels of health protection than today's calculus of costs and benefits would dictate.

It might be possible, within the context of a commodity cost-benefit model, to elicit individuals' preference for diverse levels of environmental quality: For example, many might prefer relatively polluted rivers in industrial areas (because of high clean-up costs and low recreational benefits) and quite clean streams in pristine areas. See J. DALES, POLLUTION, PRICES AND PUBLIC POLICY 51-76 (1967) (discussion of "separate facilities"). But it would be far more problematic to extract an individual commodity-like preference for living in a society structured to promote diversity. When it excludes non-commodity values, regulation dictates a partial conception of the good.

115. Regulatory decisions, in contrast to most individual commodity consumption choices, often determine the social and physical environment in relatively enduring and pervasive ways. This circumstance makes current preferences a less appealing basis for regulatory decisions, and invites aspirational consideration of the values regulation should serve. Commodity choices by market consumcrs concededly influence their future preferences. With a few exceptions such as drugs and tobacco, however, government does not attempt to regulate consumers' choices with a view to preferenceformation. This reluctance to intervene reflects several factors: the difficulty in framing a coherent and workable set of guidelines for intervention, a preference for decentralized approaches, and the fact that potential "commodity bias" is checked by the existence of flourishing non-market sectors in which decisions are made collectively and resources mobilized on the basis of non-commodity considerations. If, however, collective decisions by government were based exclusively on commodity values, the danger of shaping preferences in an exclusively commodity-consumption direction would become far more serious. See S. KELMAN, WHAT PRICE INCENTIVES? 27-92 (1981) (discussing ways in which government regulatory measures, including choices among various regulatory incentives and sanctions, shape preferences); Stewart, supra note 6, at 1704-06 (same). 
non-commodity values in regulation? What regulatory measures are best calculated to promote non-commodity values? I essay a preliminary treatment of these questions.

Governmental measures to promote non-commodity values may be challenged as inconsistent with liberal principles on the ground that goals such as "good" programming and pristine environments favor particular, controversial conceptions of the good and advantage selected interest groups. ${ }^{116}$ If so, one may ask whether the "more ample" form of liberalism sketched above is liberalism at all. When regulatory programs are based neither on rights nor on wealth maximization, they arguably represent a selectively weighted conception of the good (with an implicit condemnation of those who do not endorse it) and the use of government power to shift wealth in favor of those who share that conception. ${ }^{117}$ The counterargument is that measures which secure non-commodity values simply enlarge the portfolio of opportunities for citizens to realize their chosen conceptions of the good. So long as the enlarged portfolio is a catholic one, the principle of neutrality is not violated. That particular interests may be advantaged or disadvantaged as a result of such measures is inevitable and incidental. Measures to secure rights have similar effects, which do not by themselves render such measures illiberal.

The danger that non-commodity regulation may violate liberal principles varies depending on the particular value in question and on the regulatory strategy for securing it. This danger is least grave in the case of measures designed to secure mutuality. The geographically uniform air quality standards in the federal Clean Air Act serve mutuality because they provide the same degree of regulatory protection to all citizens, even though the cost to society of achieving a given level of air quality is likely to be higher in more heavily industrialized regions. Uniform standards might thus be attacked as illiberal on the ground that they transfer wealth from citizens in less industrialized areas, where control costs are lower, to those in more industrialized areas. ${ }^{118}$ But this claim is unpersuasive. Pre-

116. Ronald Dworkin states that most law defining and implementing social, economic, and foreign policy cannot be reduced to rights and instead the majority's view of the common good, which "cannot be neutral." R. DWORKIN, supra note 112, at 205. But he also states that this conception of the common good must be that of the community as a whole and not that of particular factions. Id. To the extent that it goes beyond wealth maximization, this conception must not embrace community ideals that "are controversial" within the community. Id. at 274. Borrowing Dworkin's terminology, we can ask whether non-commodity values are "controversial" in this sense.

117. Many environmental programs apparently provide disproportionate benefits to the wealthy and well-educated. See R. STEWART \& J. KRIER, ENVIRONMENTAL LAW AND POLICY 71-73 (2d ed. 1978). Efforts to promote "quality" broadcasting have a similar effect.

118. On the other hand, the benefits of pollution control will be greater in industrialized areas to the extent that more people live there. But it is improbable in the extreme that geographical variations in costs and benefits would everywhere balance out so as to make geographically uniform standards wealth-maximizing. 
sumptively equal enjoyment of collectively provided benefits and opportunities in fact seems more consonant with the liberal principle of neutrality than a system which denies protection to some simply by virtue of their residence. One would hardly suppose, for example, that equal levels of police protection would violate liberal principles simply because the costs of securing such protection varied geographically. ${ }^{\mathbf{1 1 0}}$

Measures to promote civic virtue also seem relatively invulnerable to the charge of illiberalism. Indeed, encouraging all citizens to learn about, and participate in, collective decisionmaking concerning government provision of collective benefits is calculated to prevent rather than create violations of liberal principles. ${ }^{120}$ Encouraging civic participation can hardly be attacked as a wealth-redistributing imposition that transgresses the requirement that public power be used for the public good. Those who prefer to remain disengaged from politics may claim that such measures violate neutrality. ${ }^{121}$ This claim is not compelling: They remain free not to participate in public affairs. ${ }^{\mathbf{1 2 2}}$

Regulatory measures aimed at securing diversity and promoting aspiration cause more difficulty. Measures designed to promote diversity usually subsidize particular preferences for consumption at levels higher than the market would sustain. The preservation of wilderness areas or classical music broadcasting formats are examples of such policies. Moreover, it is often impossible to justify such measures in the name of mutuality as corrections to wealth-dominated inequality of the market, since the preferences subsidized are often disproportionately those of the relatively affluent and well educated. These facts give rise to inferences of private wealth redistribution and perhaps also of implicit condemnation of others' preferences.

Diversity can be viewed as a cautious or weak form of aspirational strategy. It provides opportunities and experiences that might not otherwise be available to individuals. If an individual chooses to avail herself of these opportunities, she may come to criticize and change her current consumption patterns. An aspirational monopoly, on the other hand, effectively eliminates choice in relevant respects. Consider, for example, a re-

119. The right to a minimum income may be seen as an expression of mutuality in the market context, where "in kind" mutuality would be administratively costly and seriously wealth-reducing.

120. This is a basic premise of John Ely's "representation-reinforcing" strategy. See J. ELY, supra note 2 , at 73-181.

121. See generally M. WALZER, OBLIGATIONS (1970) (discussing relations between political participation and obligation to abide by collective decisions).

122. This claim, however, does become somewhat more persuasive when public resources underwrite such participation. Much of the current controversy over statutory fee awards for public interest advocacy, sec, e.g., Ruckleshaus v. Sierra Club, 103 U.S. 3274 (1983); Lawyers on the Dole, Wall St. J., Sept. 8, 1982, at 31, col. 1; OMB's "Wall of Separation" against Tax-Funded Advocacy, REGULATION, Jan./Feb. 1983, at 8, seems to reflect aversion to public funding of ideological advocacy. 
quirement that all television broadcasters show news and documentaries from 7 to 11 p.m., or air quality regulations that prevent industrial and commercial development in order to preserve visibility. Because they foreclose choice, such measures cannot be justified on the "portfolio" argument that non-market regulation is liberal because it simply expands opportunities for individual choice. ${ }^{\mathbf{1 2 3}}$

Moreover, it cannot be assumed that regulation is always a necessary or appropriate means of promoting non-commodity values. As discussed below, experience shows that some regulatory efforts-such as the FCC's promotion of local broadcasting in the name of civic virtue or protection of existing broadcasters in the name of quality programming-have actually stifled non-commodity values.

On the other hand, market arrangements are not always inimical to non-commodity values. By decentralizing economic decisions, promoting voluntary ordering, and responding flexibly to diverse preferences, market arrangements can help secure important non-commodity values. ${ }^{124}$ Even when government does intervene, there are options other than regulatory controls. For example, government may elect to stimulate certain forms of private associational activity in order to promote non-commodity values. The provisions of the Internal Revenue Code which exempt many voluntary associations from taxation and allow tax deductions for contributions to them ${ }^{125}$ have probably done more to advance non-commodity values than a slew of federal regulatory programs.

Conflict between non-commodity values and liberal principles is perhaps most acute where no serious economic market failure exists, and regulation is undertaken solely to promote non-commodity values. Consider, for example, an aspirational ban on snack foods or a compulsory adult education law. ${ }^{126}$ Such situations do not involve indivisibilities that mandate a uniform regime. Nor does the asserted commodity bias of the market provide a compelling justification for such measures. ${ }^{127}$ The suppres-

123. Attempts to justify such measures as an "education"-which those who are forced to undergo will later come to endorse-seem little better than a rationalization of paternalism infused with condemnation of the values of those who do not share the aspiration.

124. See I. KIRZNER, PERCEPTION, OPPORTUNITY AND PROFIT 225-28 (1979).

125. I.R.C. § 501 (1982).

126. While such measures might conceivably be justified on a variety of market failure grounds, see Kennedy, supra note 12, at 596-604 (discussing how almost any regulatory measure might be rationalized as correcting market failures), the analysis in the text proceeds on the more realistic premise that they cannot.

127. Market arrangements are themselves structured by legal rules that will embody some mixture of conceptions of rights, commodity values, and non-commodity values. Cf. Kennedy, supra note 12, at 596-614 (compulsory rules are chosen to promote efficiency). Accordingly, the appraisal of alternative market and regulatory regimes from the viewpoint of non-commodity values must consider the extent to which market arrangements are already structured by legal rules embodying noncommodity values. 
sion of individual choice and association that such aspirational regulation entails is likely to be a greater threat to liberal principles than any bias in favor of market values that a failure to regulate may generate. ${ }^{128}$ As this example shows, neutrality is a complex idea that counsels a pragmatic appraisal of and balance among different regimes of choice and ordering. ${ }^{129}$

The case for cultivating non-commodity values through regulation is far stronger when serious economic market failures exist. Natural monopolies, environmental spillovers, and highly imperfect information represent market failures precisely because they disable individual or associational choice. ${ }^{130}$ Accordingly, the strongest cases for regulation on wealth-maximizing grounds are often also those where the liberal virtues of private ordering would be weakly served by not regulating. Such situations typically involve indivisibilities that require a collective solution. One cannot, for example, have at the same time in the same air basin lax standards that permit industrial development and stringent standards that protect scenic values and associated lifestyles. Using a wealth-maximizing approach to resolve this choice unjustifiably excludes non-commodity values. Imposing stringent standards in the name of aspiration or diversity risks offending liberal principles for other reasons. A choice must nonetheless be made. In such circumstances what is needed are strategies that secure non-commodity values while providing the widest possible scope for decentralized initiative and choice. Examples of such strategies include the following:

Diversity rather than policy monopoly-The dangers of illiberalism are much reduced by strategies that leave citizens free to choose among several alternatives generated by different systems of collective choice. For example, an FCC requirement that all stations broadcast Shakespeare in prime time is more vulnerable to a charge of illiberalism than assignment of a single channel to a public television network that carries Shakespeare.

Decentralization as a preferred strategy-Regulation that promotes decentralization of collective decisionmaking reduces the danger of illiberalism. ${ }^{131}$ Decentralization that generates diversity through experimental va-

128. Moreover, less restrictive alternatives such as governmental provision of information or tax subsidies for education are typically available. For discussion of the limits of "aspirational" goals in environmental regulation, see Henderson \& Pearson, Implementing Federal Environmental Policies: The Limits of Aspirational Commands, 78 COLUM. L. REV. 1429 (1978).

129. $C f$. A. HIRSCHMAN, SHIFTING INVOLVEMENTS: PRIVATE INTEREST AND PUBLIC ACTION 13234 (1982) (frustration of individual preferences causes swings between market-based and government regimes, but balance is needed).

130. Such market failures cause widespread but individually small harms. Individuals will typically not find it worthwhile to redress such grievances, either by litigation or by bargaining, and transaction costs impede associational efforts at redress.

131. T. Schelling, Analytical Methods and the Ethics of Policy 20 (Harvard Inst. Econ. Research 
riation is presumptively preferable to centralized dictation of a particular pattern of diversity. Under a decentralized approach, the mobility of citizens and of capital also provides a safeguard against aspirational overreaching. ${ }^{132}$ Accordingly, the FCG may better promote diverse television programming and civic virtue by providing for local regulation of cable television than by central regulation of over-the-air broadcasters who are protected from cable competition.

Public funding rather than "taxation by regulation"-Governments can also reduce the dangers of illiberality by financing legislative programs that promote non-commodity values through the public fisc rather than by establishing regulatory measures that place the entire burden on those subject to regulation. Those subjected to regulations substantially prohibiting economic development of wetlands, for example, might plausibly claim to be victims of a coerced private wealth transfer in favor of environmentalists. Alternatively, they might claim that the regulations violate the neutrality principle, by conscripting them into the service of an environmental ideology which they reject. ${ }^{133}$ This claim is strengthened to the extent that the responsible administrative agency is seen as an environmental advocate. On the other hand, the claim is much weaker when the regulations provide for compensation. Under such a system, the potential "victims" are taxpayers equipped to prevent violations of liberal tenets through the political process' assessment of competing claims to public resources. ${ }^{134}$

Discussion Paper No. 792) (1980), notes the danger of paternalism in decisions by the federal government:

It is characteristic of policy makers, especially at the level of federal government in a nation of 200 million, that they are usually making decisions that affect others, not themselves. Hurricane and tornado warnings are for people who live where the hurricanes and tornados strike; mine safety is a responsibility of legislators and public officials in offices aboveground concerning the lives of people "out there" who work underground. Policies toward the senile, the comatose, the paralyzed and the terminally ill are deliberated by people who are none of the above. Occasionally the legislator debating a 55 mile speed limit pauses to think whether the benefits in safety to his own family will be worth the added driving time, but if he or she is conscientious that personal calculation may be surreptitious.

The situation must be different when a very small community considers a mobile cardiac unit or a new fire truck. The question then is not what we ought to spend to save someone else's life but what we can afford to make our lives safer.

Schelling goes on to suggest that the shift of the choice situation from one that is "other-regarding" to one that is "collectively-self-regarding," id. at 21, may promote the use of economic tradeoffs between the benefits and costs of regulation unencumbered by paternalistic inhibitions, although he notes that it may facilitate consideration of other normative concerns as well.

132. The value of state experimentation was celebrated by Justice Brandeis, who argued against using the due process clause to restrict state regulatory schemes. See New State Ice Co. v. Liebmann, 285 U.S. 262, 311 (1932) (Brandeis, J., dissenting).

A recent theoretical analysis of state officials' incentives for innovation, Rose-Ackerman, RiskTaking and Reelection: Does Federalism Promote Innovation?, 9 J. LEGAL STUD. 593 (1980), is skeptical about the potential for such innovation.

133. Again, assume that the decision to regulate wetlands development violates no rights.

134. Perhaps regulation is justified not by correcting market failures or promoting non-commodity values, but by securing rights to a minimum income or in-kind benefit. See Kronman, Contract Law 
Analysis of costs and benefits-It would mock the very notion of noncommodity values to tie the extent of their implementation to the market measure of individual willingness to pay for them. ${ }^{135}$ But a kind of "apples and oranges" analysis could seek to measure the economic costs of policy alternatives and the extent to which they would promote or undermine non-commodity values. Such an analysis-which most regulatory programs conspicuously lack-would not only help identify the most costeffective implementation strategies, but also promote a more informed judgment whether effort to implement the value in question is desirable.

These various strategies are not panaceas. Aspirational measures-such as Shakespeare on public television-that leave other options open to citizens may not be very effective in influencing individuals to reassess their preferences. Many people may not bother to tune in Shakespeare on public television when network entertainment alternatives are readily available. Decentralizing collective decisionmaking may not promote diversity. Given a national market, capital mobility, and transboundary spillovers, total decentralization of pollution control policies to the states may result in relatively uniform, relatively low levels of environmental protection. Accordingly, centralized measures may be necessary despite their hazards.

Some may find the conflicts and tensions between non-commodity regulation and liberal values evidence of inherent and perhaps fatal "contradictions" in liberalism. They are, however, more properly understood as reflecting fidelity to the necessary complexities in the idea of an industrial society that affirms individual and associational pursuit of diverse ends. Antiseptic neutrality among competing visions of the good is impossible in cases of collective choice, and collective choices are inevitable in cases involving indivisibilities. ${ }^{136} \mathrm{~A}$ society that seeks to nurture diverse forms of

and Distributive Justice, 89 YALE L.J. 472, 499 (1980) (redistribution through regulation of contractual terms). Economists have criticized reliance on regulation to achieve distributional objectives on the ground that tax measures can achieve those objectives without the reduction in aggregate economic welfare that regulatory measures involve. See R. ZECKHAUSER, USING THE WRONG TOOL: THE PURSUIT OF REDISTRIBUTION THROUGH REGULATION (1979). I do not wish to argue that issue here. Liberal principles cannot rule out regulation designed to secure rights to a minimum income or to particular commodities or opportunities. It is, however, quite likely to be difficult to justify particular regulatory measures on such grounds. Ensuring a minimum overall level of income or wealth for all citizens is far better accomplished through taxes and cash income transfers than through a series of disparate and poorly coordinated regulatory measures. See Stewart, supra note 6, at 1707 . Moreover, it will rarely be feasible to specify a right to particular regulatory protections or opportunities. See supra pp. 1556-68. Finally, experience suggests that regulatory programs with distributional objectives, such as regulation of entry and prices in interstate trucking to ensure "fair shares," can readily be transformed into a form of private wealth redistribution that is far less visible politically than taxation and spending decisions. Accordingly, proposals to secure distributional objectives through regulation rather than taxation should be disfavored.

135. See supra note 114 .

136. Any choice among legal rules, including choices about how to allocate decisionmaking competence among various private and political decisionmakers, involves such indivisibilities, see Tribe, supra note 17 , at 11 . 
excellence must struggle to promote non-commodity values while maintaining a large scope for individual and associational initiative. A more ample liberalism-one that accommodates non-commodity values-does not pretend to have formulaic answers to the complexities inherent in this enterprise. And that is precisely one of its virtues.

\section{The Existing and Future Role of Non-Commodity Values in Regu- latory Law}

This section builds upon the general framework developed in the previous section to analyze environmental and broadcast regulation. It also considers the implications of non-commodity values for administrative law.

\section{A. Non-Commodity Values in Existing Regulatory Programs}

Non-commodity values play an important role in existing regulatory programs. Environmental and broadcast law illustrate how explicit recognition of non-commodity values and their distinctive characteristics can help explain many otherwise puzzling features of regulatory programs. They also illustrate some of the hazards in pursuing non-commodity values through centralized regulation.

Non-commodity values are reflected in such diverse regulatory policies as wilderness preservation, "technology-forcing" pollution control measures, environmental standards based solely on health considerations, and FCC efforts to promote "good" programming. Regulatory programs that mandate pristine and healthful environments or commercially unpopular forms of broadcasting are generally not wealth maximizing. ${ }^{137}$ There is, for example, no apparent reason why a private market in wilderness experiences could not function adequately to maximize wealth. ${ }^{138}$ Governmental management and regulation to promote preservation can best be

137. An economic analysis based on market failure might dictate some "technology forcing" environmental measures, on the theory that inducing innovation in control technologies is cost effective. See Stewart, supra note 38. It might also dictate some "free" over-the-air broadcast regulation because of the market failure associated with advertising sponsorship, see supra p. 1565. But it is extremely implausible that such a calculus could justify the prevailing rigor and extent of such regulation, or that it could serve at all as a justification for wilderness preservation or health-based environmental standards.

138. There is, for example, no apparent reason why private entrepreneurs could not satisfy "option demand"-the demand for the future opportunity to visit scenic areas-through a futures market. Another asserted justification for government ownership or regulation of natural resources-the preservation of scenic environments for future generations-is similarly uncompelling. Insofar as this desire runs only to one's direct descendants, a private market system could accommodate it. A private market system cannot satisfy a collective interest in preservation of wilderness areas for future societies, but the desire to preserve resources in such a specific form must be explained by non-market values of diversity or aspiration. 
understood as an effort to support and encourage a preference for noncommodity experiences such as contemplation. ${ }^{139}$

Diversity is a slightly weaker means of promoting non-commodity values because it fosters a variety of conditions and opportunities without endorsing any particular one. Federal air quality standards ${ }^{140}$ are an example of aspiration because they seek to achieve the same level of air quality, based solely on health considerations, throughout the nation. The Prevention of Significant Deterioration and visibility-protection provisions, sharply limiting development in certain pristine areas, ${ }^{141}$ are an example of diversity. ${ }^{142}$ Other diversity measures include governmental efforts to generate more diverse sources and kinds of programming in prime viewing time, ${ }^{143}$ to restrict joint ownership of media, ${ }^{144}$ and to promote public television.

Environmental and broadcast policy afford several examples of policies promoting mutuality, which is a distributional aspect of non-commodity values. ${ }^{145}$ The government could sell off the public lands, eliminate preservation regulation, and thus permit the private market to supply wilderness experiences. Although this alternative might increase commodity wealth, the government has not adopted it, due in part to the belief that non-commodity opportunities like wilderness experiences should be available to citizens without regard to wealth. Another example of mutuality is the geographically uniform, health-based standards characteristic of many environmental programs. Such uniformity is economically irrational. The economic benefits of control in less populated areas are typically lower than in more populated ones, and therefore a wealth-maximizing approach would generally dictate higher permitted levels of pollution or radiation in less populous areas. ${ }^{148}$ Such a policy would, however, provide

139. See J. SAX, MOUNTAINS WITHOUT HANDRAILS (1980).

140. See Clean Air Act, 42 U.S.C. § 7402(a) (1982).

141. See id. $\S \S 7470-7491$.

142. The line between "strong" aspiration and "weak" diversity is not always clear, and depends on the definition of the class of "consumers" of the collective good being provided. For example, a Prevention of Significant Deterioration strategy may represent a diversity measure from the viewpoint of residents of the United States, but an aspirational measure from the viewpoint of residents of the areas where development is constrained. Aspirational measures may vary in their degree of "coerciveness," which might be measured by the elasticity of demand for the affected good. Nationally uniform health-based environmental quality standards are quite coercive because an individual with a preference for lower environmental quality and higher levels of economic development would have to leave the country in order to satisfy that preference. A requirement that all broadcasters show documentaries during a given hour of prime time is less coercive because a viewer who prefers light entertainment can view at other times, use a video recorder to play light entertainment during that hour, go to the movies, and so forth.

143. See D. Ginsburg, Regulation of BroadaAsting 258-93 (1979).

144. See id. at 195-243.

145. See generally G. CALABRESI \& P. BOBBITT, TRAGIC ChOICES 33 (1978) (society may wish to prohibit Pareto-superior move if wealth distribution is extremely uneven).

146. The costs of achieving a given level of environmental quality will also vary geographically, 
less protection to individuals living in small towns and rural communities. ${ }^{147}$

Civic virtue most clearly reflects the associational elements in the American liberal tradition. The FCG's efforts to promote the local ownership of broadcasting stations, the local origination of news, public affairs, and entertainment programming, and the use of survey procedures to ascertain local community interests and needs seek to foster citizen participation in community government and affairs. Such participation is a strong form of civic virtue.

The activities of national public interest advocacy groups embody a weaker form of civic virtue. These groups participate in federal agency proceedings and litigation. They provide their members and contributors with a measure of associational participation, though normally of an impersonal sort, in the development of public policy. Statutory provisions designed to encourage these activities-including section 501(c)(3) of the Internal Revenue Code, ${ }^{148}$ public participation requirements, ${ }^{149}$ and attorney fee award provisions ${ }^{150}$ - promote this form of civic virtue.

\section{B. The Performance of Non-Commodity Regulatory Programs}

Some regulatory programs have been quite successful in promoting non-commodity values. The protection of pristine scenic areas in the name of diversity, through Prevention of Significant Deterioration (PSD) provisions in the Glean Air Act, is an example. Certainly, market forces cannot

depending on the degree and type of industrial, commercial, and residential development in an area the area's topography and weather, and so on. It would be unlikely that costs and benefits would balance each other so precisely as to make geographically uniform standards economically efficient. The prevalence of geographically uniform federal standards also partially reflects administrative and political obstacles to agreement on non-uniform standards. See Zerbe, Optimal Environmental Jurisdictions, 4 ECOLOGY L.Q. 193, 210-12 (1974).

147. The value of mutuality is not absolute. The goal of providing equal environmental health protection to all citizens has been qualified in order to take into account the varying costs and burdens of control in different geographical areas and industries. For example, the Clean Air Act establishes geographically uniform air quality standards, but the higher costs of meeting those standards in heavily polluted areas are accommodated by postponing the compliance deadlines for such areas. See $\mathbf{R}$. STEWART \& J. KRIER, supra note 117, at 494-97. In the case of the Occupational Safety and Health Act, standards concerning toxic substances must be set to ensure that "no employee will suffer material impairment of health or functional capacity," but this objective is to be implemented only "to the extent feasible." 29 U.S.C. $\$ 655(b)(5)$ (1982). In practice, feasibility varies from industry to industry depending on available control technologies, the costs of such technologies, and the ability of an industry to absorb such costs.

148. The Code exempts qualifying nonprofit "religious, charitable, scientific . . . or educational" institutions from federal income tax and makes individual and corporate contributions to such organizations tax-deductible. I.R.C. $\$ 501$ (c)(3) (1982). Subject to certain limitations, these organizations may engage in lobbying and litigation and participate in administrative proceedings in order to influence public policy. See id. § 501(h).

149. See Stewart, supra note 6 , at 1748-59.

150. See generally S. BREYER \& R. STEWART, supra note 99 , at 1044-58 (discussing attorney fees for litigation successfully challenging agency action). 
be relied upon to preserve such areas; ${ }^{\mathbf{1 5 1}}$ government measures like the PSD program have a clear logic and enjoy widespread public support. ${ }^{162}$

Other programs have failed due to faulty design or the use of inappropriate incentives. The "technology forcing" efforts of the Clean Air Act ${ }^{153}$ are an example. The logic of such efforts is in large part aspirational: Society should seek to achieve healthier and purer air than a wealthmaximizing calculus based on current preferences would dictate. ${ }^{154}$ The Act's regulatory mandates were designed to force polluting industries to develop new technologies in order to achieve that goal. The technologyforcing effort largely failed, however, because the design of the program did not link technology-forcing measures with ultimate environmental objectives. ${ }^{158}$ Also, the program erred in relying on clumsy and relatively ineffective command-and-control orders to spur innovation, rather than economic incentives. ${ }^{158}$

In other cases, failure is attributable to basic flaws in the program's goals. For example, the means employed under the Clean Air Act to restrict drastically the private use of automobiles in polluted central cities included restricting access, eliminating parking spaces, and similar measures. The stated objective of the regulation was to achieve air quality goals rapidly. The measures in question were socially costly and of doubtful efficacy ${ }^{167}$ Moreover, some government officials and environmentalist lawyers seem to have forced such controls with the apparent goal of reducing use of automobiles and promoting mass transit for reasons other than improving air quality. No hard-headed assessment was made of precisely what other objectives, including non-commodity values, would realistically be served by measures that were massively unpopular and never fully implemented.

The experience in broadcast regulation also presents a mixed record. The limited number of television outlets, and the failure of advertiser-

151. See Sierra Club v. Department of Interior, 376 F. Supp. 90 (N.D. Cal. 1974) (protection of redwoods from destruction by logging operations). For subsequent developments in the case, see 398 F. Supp. 284 (N.D. Cal. 1975), 424 F. Supp. 172 (N.D. Cal. 1976).

152. The PSD provisions in the Clean Air Act of 1977, Pub. L. No. 95-95, \$§ 160-169, 91 Stat. 731 (codified at 42 U.S.C. $\$ 7470$ (1982)), represent Congress' endorsement of judicially-developed standards. See R. STEWART \& J. KRIER, supra note 117, at 476-94. Although imperfect in certain respects-they are overbroad in coverage and impose quite cumbersome new source review procedures-they have thus far withstood development-oriented efforts to weaken them substantially.

153. See La Pierre, Technology Forcing and Federal Environmental Protection Statutes, 62 IOWA L. REV. 771 (1977).

154. See Henderson \& Pearson, Implementing Federal Environmental Policies: The Limits of Aspirational Commands, 78 ColUM. L. REV. 1429, 1443 (1978).

155. See B. ACKERMAN \& W. HASSLER, supra note 46.

156. See Stewart, supra note 38, at 1296-1311.

157. See Chernow, Implementing the Clean Air Act in Los Angeles: The Duty to Achieve the Impossible, 4 ECOLOGY L.Q. 537 (1975); Stewart, Pyramids of Sacrifice? Federalism Problems in Implementing National Environmental Policies, 86 YALE L.J. 1202-10 (1977). 
supported broadcasting to respond to viewers' intensity of preferences for various types of programs, could justify regulation promoting program variety on wealth-maximizing grounds alone. ${ }^{158}$ When non-commodity values such as diversity and civic virtue are considered, the case for regulation seems even stronger. For over 30 years, the FCG, with considerable judicial prodding, has instituted a wide variety of program measures to promote such values. Even in their prime, such efforts were widely condemned by critics as ineffective. Today, the FCC, with the administration's encouragement and Congress' acquiescence, is abandoning most of those efforts in the name of deregulation. What explains this apparent failure?

Gertainly, there have been failures of design. The effort to promote local broadcasting by geographical dispersion of stations flew in the face of scale economies in broadcasting. It aggravated the scarcity problem by generating only three networks; alternative allocations could have generated six or seven. ${ }^{159}$ The efforts to promote local program origination and non-network prime time programming similarly foundered on the realities of broadcast economics. ${ }^{130}$

Whether these failures of design were foreseeable, and therefore avoidable, is debatable. It is clear, however, that the FCG persisted in such efforts after their failure became apparent. Such inertia is attributable to bureaucratic tunnel vision and the interest of those who benefit from prevailing regulatory policies. For example, a reallocation of broadcast stations to permit the development of more networks would be bitterly opposed by the existing networks and by localities that would lose stations.

Regulatory inertia has also hindered the market development of new broadcasting technologies. Many of these technologies, including cable and subscription television, would serve diversity and facilitate local programming by reducing scarcity. ${ }^{101}$ The FGC's efforts to regulate the existing industry in order to promote non-commodity values delayed the development of new market-based products and services that promise to serve many aspects of diversity far better.

Finally, an air of paradox inevitably infects government efforts to use centralized regulation in order to promote better or more diverse program-

158. The empirical evidence tends to show, however, that there may be greater demand for programs of the sort already carried by networks-entertainment, adventure, situation comedy-than for programming of a different sort. See H. LEVIN, supra note 76.

159. See R. NOLL, M. PECK \& J. MCGOWAN, supra note 99, at 116; B. OWEN, J. BeEKE \& W. MANNING, TELEVISION ECONOMICS 19 (1974).

160. See, e.g., Prime Time Access Rule, 50 F.C.C.2d 829, 889 (1975) (Commissioner Robinson dissenting) (explaining reasons why rule failed to obtain goal of stimulating diverse, high quality nonnetwork programming in prime time); B. OWEN, J. BEEKE \& W. MANNING, supra note 159, at 10 (unfavorable economics of local broadcasting).

161. See R. CASS, supra note 76; I. POOL, TECHNOLOGIES OF FrEEDOM (1983). 
ming. The FCC never clearly stated whether its objective was the strongly aspirational goal of better programs and more informed citizens or the weaker goal of diversity. The FCC was also uncertain of the precise content that might be given to these objectives. No doubt an important constraint was the fear that explicit dictation of program requirements would undermine the goal of diversity and violate liberal principles. ${ }^{162}$ Given these difficulties, it would be comforting if deregulated markets turned out to serve non-commodity values better than regulation. We should hesitate, however, to conclude that the FCC's past efforts were a total failure or that deregulation is a complete solution. The FCC's "raised eyebrow" probably had a beneficial impact in promoting the development of highquality documentaries and in launching network news. It is not clear how far new technologies will satisfy non-commodity values of aspiration or diversity, ${ }^{163}$ though cable systems invite a measure of local or state regulation that may present opportunities to promote civic virtue. ${ }^{164}$

The record of these and other regulatory efforts underscores the need for specifying non-commodity objectives, determining whether regulation is likely to advance them, and designing effective measures to promote them. This task will require far more work in developing our rudimentary understanding of non-commodity values, which have largely been ignored by the emerging disciplines of policy analysis. There is a rich literature dealing with market failures, alternative correctional tools, costbenefit methodology, and other topics related to commodity values. Although some scholars have made an important beginning, ${ }^{185}$ nothing comparable exists in the case of non-commodity values. ${ }^{168}$

162. These principles are reflected in judicial interpretation of the First Amendment and the prohibition of FCC "censorship" in 47 U.S.C. $\S 326$ (1982).

163. There are, for example, indications that pay cable television cannot be relied on to generate high-quality programs including serious drama and opera. See How a Cable System Flopped, N.Y. Times, Feb. 28, 1983, at D1, col. 3; O'Connor, Ahead for Cultural Programming, N.Y. Times, Dec. 12,1982 , at $\mathrm{H33}$, col. 1 . For discussion of the limited potential of deregulation for promoting program variety, see Note, supra note 30. See also Mayer, Netweorks Are Accused of Neglecting Children in Era of Deregulation, Wall St.J., Mar. 17, 1983, at 1, col 1.

164. But see Community Communications, Inc. v. City of Boulder, 455 U.S. 40 (1982) (applying federal antitrust law to municipal regulation of cable television).

165. See supra notes 108-09; S. KELMAN, supra note 115.

166. Professor Steven Kelman, for example, advocates that some resource allocation decisions be made by non-market methods of choice, in order to develop what this Article calls non-commodity values. S. KELMAN, supra note 115 . But this general principle provides no guidance in determining whether and to what extent any given subject-matter decision-television program format, for example-should be reserved for one sector or another, or how non-market choices should be made. See also Note, supra note 101 (discussing problems with determining which public lands are to be reserved for wilderness or similar purposes). 


\section{The Courts' Treatment of Non-Commodity Values}

Cass Sunstein and I have argued elsewhere that the various remedial "forms of action" in administrative law reflect three conceptions of the regulatory purpose: the vindication of entitlements, the production of wealth, and the advancement of other public values. ${ }^{167}$ The analysis in this Article builds upon that framework, identifying aspiration, diversity, mutuality, and civic virtue as key public values. A survey of judicial decisions in the broadcast and environmental areas shows that courts have often construed agencies' responsibilities to include the promotion of noncommodity values. The D.C. Gircuit, which exercises exclusive reviewing powers over most FCC decisions, has promoted regulatory efforts designed to encourage diverse, informative, high quality programs. When the FCC has seemed laggard in this effort, the court has overruled the Commission in order to promote "higher quality" programming, ${ }^{168}$ foster local broadcasting, ${ }^{168}$ and extend the fairness doctrine, which requires presentation of differing views on controversial issues of public importance. ${ }^{170}$ Explicitly invoking the notion of "diversity," the court has required the Commission to preserve existing "quality" program formats" ${ }^{171}$ and to prohibit joint ownership of newspapers and broadcast stations. ${ }^{172}$

Two powerful undercurrents appear to motivate these decisions, which

167. See Stewart \& Sunstein, supra note 3, at 1239-40.

168. In the name of promoting better quality broadcasting, the D.C. Circuit has interpreted the hearing requirements of the Communications Act to restrict the FCC's power to favor existing licensees in license renewal proceedings. See Citizens Communications Center v. FCC, 447 F.2d 1201 (D.C. Cir. 1971). It suggested that the FGC consider as aspects of "superior" broadcast performance the "elimination of excessive and loud advertising" and "delivery of quality programs." Id. at 1213 n.35. Also relevant to evaluating quality of performance was the extent to which a broadcaster had "reinvested the profit on his license to the service of the viewing and listening public." Id.

169. When, for example, the Commission declined to apply its policy favoring license applicants who promise local programming to a case involving a suburban broadcast outlet in a large metropolitan area, the court forced the Commission to adhere to that policy. See Pasadena Broadcasting Co. v. FCG, 555 F.2d 1046 (D.C. Cir. 1977).

170. After the Commission had applied the doctrine to advertising for the first time in the case of cigarette commercials, it declined to apply it to environmental issues assertedly raised by gasoline advertising. The court reversed. Friends of the Earth v. FCC, 449 F.2d 1164 (D.C. Cir. 1971).

171. The D.C. Circuit discerned the diversity principle in the opaque "public interest, convenience and necessity" language of the Communications Act. Invoking this principle, it has required the Commission to review changes in radio broadcasters' program formats when the change (for example, from classical to rock music) might eliminate the last instance of a given format (classical music) in a community. See Citizens Comm. to Save WEFM v. FCC, 506 F.2d 246 (D.C. Cir. 1974) (en banc) (classical music); Citizens Comm. to Preserve the Voice of the Arts, WGKA-FM v. FCC, 436 F.2d 263 (D.C. Cir. 1970); Citizens Comm. to Keep Progressive Rock v. FCC, 478 F.2d 926 (D.C. Cir. 1973).

172. The D.C. Circuit concluded that the diversity principle requires that existing newspaperbroadcaster cross-ownership arrangements be dissolved, although the Commission had sought to ban such arrangements only prospectively. National Citizens Comm. for Broadcasting v. FCC, 555 F.2d 938 (D.C. Cir. 1977), rev'd in part, 436 U.S. 775 (1978). In addition, the court suggested that avoidance of concentration in media ownership should be a factor in license-renewal proceedings. Sce Citizens Communications Center v. FCC, 447 F.2d 1201, 1213 nn.35 \& 36 (D.C. Cir. 1971). 
reflect a persistent use of suppletive principles by judges to redirect agency decisionmaking. The first is a deep distrust of Commission backsliding in response to the economic and political power of the broadcasters. The second is a concern to promote non-commodity values of diversity, aspiration, and civic virtue in the "wasteland" of advertiser-sponsored, networkdominated television. These currents surfaced in the D.C. Circuit's decision in Home Box Office, Inc. v. FCC, ${ }^{173}$ invalidating FCG programming restrictions on cable television. The court found that such restrictions, adopted by the FCC in order to protect over-the-air broadcasters, violated the First Amendment as well as the diversity principle which the court found implicit in the Communications Act. ${ }^{174}$ It concluded that diversity would be far better served by removing restrictions on market entry. ${ }^{175} \mathrm{~A}$ belief that established broadcasters had "captured" the Commission and negotiated a self-serving deal that violates liberal principles is transparent in the court's opinion. ${ }^{178}$

In Home Box Office the court championed a form of deregulation that it believed would serve the interest in diversity better than did Commission regulation. Recent years have witnessed a more general movement in favor of deregulation. Although greater diversity was the goal of the deregulation championed by Home Box Office, the deregulation movement has also been fueled by public reaction to perceived regulatory excesses, ${ }^{177}$ and by a heightened societal interest in the production of wealth. There has been a corresponding cutback, led by the FCC and endorsed by the Supreme Court, in regulatory ventures designed to secure non-commodity values. In connection with broadcasting, many of the policies encouraged or initiated by the D.C. Circuit have been truncated or abandoned. ${ }^{178}$ For

173. 567 F.2d 9 (D.C. Cir.), cert. denied, 434 U.S. 829 (1977).

174. 567 F.2d at 27. See FCC v. National Citizens Comm. for Broadcasting, 436 U.S. 775 (1978). But see FCC v. Pacifica Foundation, 438 U.S. 726 (1978) (upholding FCC's authority to forbid radio broadcast of words that were short of "obscene").

175. Home Box Office, 567 F.2d at 39.

176. See id. at 33 .

177. See supra p.1543.

178. The Supreme Court has rejected a claimed "right to access" whereby private groups would be entitled to purchase time in order to air political messages. See Columbia Broadcasting System, Inc. v. Democratic Nat'l Comm., 412 U.S. 94 (1973). It also reversed a D.C. Circuit holding requiring that the FCC's ban on newspaper-broadcast cross-ownership be applied to all existing combinations. See FCC v. National Citizens Comm. for Broadcasting, 436 U.S. 775 (1978). The Supreme Court has also endorsed the Commission's new policy of relying on marketplace competition to promote diversity, overruling the D.C. Circuit's decisions to the contrary. See FCC v. WNCN Listeners' Guild, 450 U.S. 582 (1981).

At the same time, the Commission has cut back on regulatory requirements, including those limiting the amount of commercial advertising and those requiring public service programs by radio broadcasters. See Fowler \& Brenner, A Marketplace Approach to Broadcast Regulation, 60 TEX. L. REV. 207 (1982) (general description and defense of the FCC's recent deregulated "marketplace approach" to broadcasting); see also Malrite T.V. of New York v. FCC, 652 F.2d 1140 (2d Cir. 1981), cert. denied, 454 U.S. 1143 (1982) (upholding FCC removal of restrictions on cable television program- 
reasons previously canvassed, it may turn out that wide-scale deregulation, coupled with the growth of new communications technologies, may better serve non-commodity values such as diversity than do the regulatory policies favored by the D.G. Gircuit and previous Commissions.

The history of broadcast regulation can be understood as an exfoliating process of incremental search for the proper relation between noncommodity values and regulation. ${ }^{179}$ While "muddling through" may be the inevitable mode of learning in public policy, better analysis-building upon the economic and public-policy literature-might have prevented some wrong turns and dead ends. ${ }^{180}$ The failure of Home Box Office and decisions requiring preservation of particular program formats to distinguish between commodity and non-commodity regulatory objectives ${ }^{\mathbf{1 8 1}}$ illustrates the lack of such analysis. Such failure on the part of courts is understandable, given their institutional limitations. ${ }^{182}$ Far less excusable is the FCG's failure to use available economic and policy analyses in its decisions. ${ }^{183}$

The record of judicial review of administrative action in the environmental field differs from that in broadcasting in important respects. Most environmental statutes explicitly endorse the promotion of non-commodity values such as wilderness preservation and health protection. These values often have a quantifiable physical expression or analogue, such as acres of wilderness preserved or quantities of air pollutants removed. ${ }^{\mathbf{1 8 4}}$ It has also

ming); In re Deregulation of Radio, 49 RAD. REG. 2d (P \& F) 1, 25-31 (1981) (repealing FCC guidelines respecting maximum number of commercial minutes per hour on radio); Report and Order, 49 RAD. REG. 2d (P \& F) 1, 8-14 (eliminating non-entertainment program guidelines); Termination of Rulemaking, 46 Fed. Reg. 48,710 (1981) (termination of "kid-vid rulemaking" considering restrictions on television advertising directed at children). The D.C. Circuit itself has displayed second thoughts about the fairness doctrine and has limited its reach. Consider, for example, the tortured procedural history of National Broadcasting Co. v. FCG, 516 F.2d 1101 (D.C. Cir. 1974) (50 page opinion followed by order scheduling rehearing en banc, vacating of that order, vacating of panel's opinion, and remand to FCG with order to vacate its order), cert. denied sub nom. Accuracy in Media, Inc. v. National Broadcasting Co., 424 U.S. 910 (1976).

179. See J. KRIER \& E. URSIN, POLLUTION AND POLICY 298-307 (1977) (discussing concept of policy "exfoliation").

180. For examples of such analysis, see H. LEVIN, supra note 76; R. NOLL, M. PECK \& J. MCGOWAN, supra note 99.

181. Consider, for example, the issues in Home Box Office. Would removal of program restrictions on cable result in undesirable "siphoning" or "cream skimming" by which the most desirable programs would be snapped up by cable, leaving an inferior residue for viewers of "free" over-the-air broadcasting? The issue can be seen in economic terms: Would this shift, to the extent that it is likely to occur, result in a loss of consumer welfare? Or can it be seen in terms of non-commodity values: Would such a shift increase the overall diversity and quality of programming? To what extent would mutuality be undermined by conditioning access on ability to pay? The court of appeals failed to recognize or pursue these questions.

182. See supra pp. 1537-38.

183. See Citizen's Comm. to Preserve the Voice of the Arts, WGKA-FM v. FCC, 436 F.2d 263 (D.C. 1970). The Commission's failure to use available economic understanding in promulgating a prime-time access rule was cogently criticized by Commissioner Glen Robinson. See supra note 160.

184. There are, however, often grave uncertainties in determining the health or ecological risks 
proven far easier for courts to identify some of the economic costs associated with regulatory measures, particularly in the case of pollution control. ${ }^{185}$

By requiring agencies to take a hard look at the environmental, economic, and technological variables involved in regulatory choices, courts hope to promote an appropriate balance between production and environmental values. This balancing process, however, is generally unstructured and leaves out important costs, such as delay and uncertainty, that have no ready market measure. Moreover, the benefits of environmental protection are not broken down into their commodity and non-commodity components. These gaps help explain why courts have failed to develop a successful structure for making decisions. ${ }^{188}$

Although the "balancing" process spawned in pollution and toxicchemical cases is extremely crude and incomplete, it represents an advance over the situation prevailing in cases involving natural resource management and regulation. The opportunity costs of not developing resources are often inherently difficult to measure. For example, the economic value of the mineral development foregone by classifying federal lands as wilderness can, as a practical matter, only be determined by opening them to exploration and development in order to determine what minerals lie hidden below the surface. ${ }^{\mathbf{1 8 7}}$ The determination of benefits presents special difficulties as well. While the number of acres in a wilderness can be precisely measured, their qualitative importance cannot. This difficulty reflects in part the problem of aggregation. In resource management, administrative decisions and judicial review typically focus on particular choices regarding particular parcels of land. But this "retail" focus is illequipped to deal with non-commodity values, such as diversity, that arise

associated with various forms of environmental disruption. See Industrial Union Dep't v. American Petroleum Inst., 448 U.S. 607, 630-36 (1980) (health experts disagree on dangers of occupational exposure to benzene).

185. For example, compliance outlays by regulated industries can be estimated. It is difficult, however, to predict cost-reducing innovations that firms may develop if forced to comply. When compliance takes the form of process changes, it may be difficult to allocate the outlays involved between regulatory compliance and production cost reductions. Also, the economic losses associated with regulatory delays and uncertainties are difficult to measure. See Stewart, supra note 38.

186. Courts profess total agnosticism on the question of how the ultimate balance is to be struck. Most courts generally reserve this choice for the responsible administrative agency to make. The closest that courts have come to formulating a consistent approach to tradeoffs is a shutdown rule which, in the case of significant health or ecological risks, permits or requires agencies to mandate controls up to the point technologically and economically feasible without shutdown of a substantial percentage of capacity. See Stewart \& Sunstein, supra note 3, at 1243-44.

187. See Tundermann, Preservation vs. Mineral Development of Withdrawn Federal Lands-Much Ado, But Little to Show, 13 ENVTL. L. REP. 10,009, 10,017 (Jan. 1983). The United States, unlike the Soviet Union, relies on industrial firms rather than government investigators to survey and explore for mineral deposits on public lands. In order to provide an adequate incentive for firms to undertake such exploration, they must be given substantial assurances that they will be permitted to develop a deposit if one is found. 
out of aggregate patterns of resource use. For example, one might conclude that diversity is appropriately served by reserving a certain proportion of wilderness lands from development. With the exception of a few superb sites, however, it may not greatly matter which parcels make up this total. Accordingly, the diversity principle provides little guidance in deciding whether a particular site should be developed-which is how the issue is usually presented to the courts. ${ }^{188}$

Despite, or perhaps because of, this aggregation problem, courts have on occasion sought to protect non-commodity values by insisting on considerable procedural rigor and clear statutory authority before an agency authorizes the irreversible development or destruction of natural resources of high aesthetic or ecological value. ${ }^{188}$ Here too, courts have developed and enforced suppletive principles in order to promote non-commodity values. These rulings can be understood as administrative law variants on the public trust doctrine. ${ }^{190}$ They represent a way of coping with institutional limitations. Courts are ill-equipped to ascertain, on either a "wholesale" or "retail" basis, the resources to be dedicated to various noncommodity objectives. Instead, courts attempt to impose a more pointed responsibility on other agencies of government, presumably institutionally better qualified, to make such decisions only upon full and explicit consideration of the non-commodity values at stake.

Courts have also supported efforts to promote non-commodity values in environmental, broadcast, and other fields of regulation by making important changes in general remedial and procedural doctrines. These changes include expanded rights of standing and intervention, relaxed principles of

188. See Note, supra note 101 , at $935-41$.

189. Judges have imposed demanding procedural requirements upon administrative decisions to locate an energy facility in an ecologically vulnerable or exceptionally scenic area. See, e.g., Seacoast Anti-Pollution League v. Costle, 572 F.2d 872 (1st Cir.), cert. denied, 439 U.S. 824 (1978); Scenic Hudson Preservation Conference v. FPG, 354 F.2d 608 (2d Cir. 1965), cert. denied, 384 U.S. 941 (1966). In the Georges Bank litigation, the court stayed the leasing of sites for offshore oil development because a bill to provide additional environmental safeguards was pending in Congress. It found that the Secretary of the Interior had fiduciary duties towards the resources in question. See Massachusetts v. Andrus, 594 F.2d 872 (1st Cir. 1979). In the case of Redwoods National Park, both state and federal courts took unusual steps to halt adjacent logging operations that threatened the ecological value of the Park. See Sierra Club v. Department of Interior, 398 F. Supp. 284 (N.D. Cal. 1975). These included a requirement that the Secretary of Interior seek additional Congressional funding to take protective measures. The courts' prohibition of significant deterioration of air quality in existing clean air areas can similarly be viewed as an effort to preserve non-market values of diversity against erosion threatened by market pressure. See Sierra Club v. Ruckelshaus, 344 F. Supp. 253 (D.D.C. 1972), aff'd by an equally divided court, 412 U.S. 541 (1973); Stewart, supra note 111, at 718-20.

190. For advocacy of judicial use of public trust principles to control administrative decisions on natural resource use, see Wilkinson, The Public Trust Doctrine in Public Land Law, 14 U.C.D. L. REV. 269, 310-11 (1980). This position is strongly criticized in Jawetz, The Public Trust Totem in Public Land Law: Ineffective-And Undesirable-Judicial Intervention, 10 ECOLOGY L.Q. 455 (1982). 
ripeness, paper record requirements, and "hard-look" judicial review. ${ }^{191}$ Expanded rights of access and participation have enabled environmental, viewer, and other public interest groups to provide a voice for noncommodity values. Such representation helps assure that regulation responds to evolving social values. ${ }^{182}$ But the new remedial principles have also benefited representatives of commodity values. Regulated firms, for example, have made very effective use of paper record requirements and hard-look review to challenge burdensome and poorly justified environmental regulations. ${ }^{103}$ With some important exceptions, the courts have primarily sought to play a regulative role. They have attempted to lead the agencies to a more informed, careful and discerning balance between-as the courts astigmatically see it-the productive benefits of unregulated markets, and the non-commodity values promoted by regulation.

\section{Conclusion}

In a liberal society, institutional design must protect liberal principles against subversion by the private economic and ideological forces that shape regulatory policy. If well-structured markets can convert the dross of private interest into the gold of collective welfare, then institutions of public governance may be capable of similar alchemy. In the context of contract law, courts help structure the play of private interests in accordance with collective norms, sometimes by imposing mandatory conditions, but more often by drawing upon supplementing principles to give deter-

191. See generally R. STEWART \& J. KRIER, supra note 117, at 618-732 (administrative law aspects of environmental law).

Home Box Office is but one example of how courts demand clear statutory authority to justify what seems to be an instance of private wealth redistribution or ideological imposition. Clear statement principles have also been applied by reviewing courts to curb ideological overreaching. One example, already noted, is the transportation control plan decisions invalidating sweeping controls on automobile use. See supra p. 1579. Another is the Supreme Court's decision in the Benzene case, Industrial Union Dep't v. American Petroleum Inst., 448 U.S. 607 (1980). There, OSHA's health standards for occupational exposure to benzene were struck down because data ensured only speculative benefits in return for industry costs in excess of half a billion dollars. A similar logic appears in Supreme Court decisions invalidating state restrictions on advertising by professionals. See Virginia Bd. of Pharmacy v. Virginia Citizens Consumer Council, Inc., 425 U.S. 748 (1976).

While the Home Box Office and EPA decisions were aimed at protecting diversity and decentralization, Benzene was aimed at preventing costly regulations that reduce wealth without substantially advancing other regulatory ends. Because of this disparity in costs and benefits, the Labor Department OSHA regulation could also be regarded as a form of private wealth transfer, by giving wellorganized petroleum workers, at the expense of consumers generally, far higher levels of protection against risk than that enjoyed by workers or the public with respect to comparable risks. Clear statement principles have also been employed by courts to protect entitlements. The creation in the labor field of fair representation duties to prevent discrimination is perhaps the most notable example. See Steele v. Louisville \& N. Ry., 323 U.S. 192 (1944).

Such judicial enforcement of clear statement principles is simply a dramatic example of the pervasive role that supplementing principles play in regulatory and administrative law.

192. See generally J. VINING, supra note 9, at 139-69 (discussing law and values).

193. See Stewart, supra note 111, at 727-33. 
minate content to agreements. In public law, the courts sometimes draw upon the Constitution to impose mandatory conditions. More often, however, their work is suppletive, using statutory interpretation and administrative law to help give shape to regulatory programs. This Article shows how the entitlement, production, and non-commodity conceptions inform this work.

This Article has outlined some of the elements of a complex theory of regulatory and administrative law, but many pieces are still missing and major questions do not have even preliminary answers. For example, each of the three conceptions examined in this Article can be understood as securing different elements of the liberal ideal of plural excellence-liberty, resources, self-development. This complexity is a virtue, for, as we have seen, the American tradition of associational liberalism cannot be reduced to a single formula. But complexity also exacts a price. A complex theory must explain the relation among its constituent elements and determine their respective competencies.

The roles played by the various conceptions in regulatory policy have varied over time and among different fields of regulation. For reasons already discussed, entitlements have played a relatively minor and often derivative role in environmental law. Although broadcast policy has been influenced by claims of entitlement based on the First Amendment, ${ }^{104}$ it, like environmental law, has been largely shaped by a dialectical interplay between commodity and non-commodity values, in which the weight given to different elements has fluctuated. On the other hand, entitlement conceptions have played a much larger role in other regulatory programs, particularly those dealing with various forms of discrimination. In still other areas of regulation, such as securities law, production concerns are dominant. This Article has not offered any general account of these variations.

A similar indeterminacy operates within the conception of noncommodity values, which itself consists of several elements with differing and sometimes conflicting implications for regulatory policy. The conception's distinctive and potentially unifying quality is its goal of promoting self-critical choice, individual or joint. ${ }^{195}$ Unlike the rights and wealthmaximizing conceptions, however, this conception has not achieved a fully developed internal logic.

194. Fear of unconstitutional censorship has no doubt contributed to the FCC's reluctance to regulate program content. In addition, broadcast licensees have successfully asserted what amounts to a de facto entitlement to license renewal based on substantial investments in licenses and renewal expectations. Despite the provisions in the Communications Act limiting licenses to a term of five (formerly three) years, see 42 U.S.C. $\$ 307$ (d) (1982), the FCC has failed to renew licenses in only a few cases. See S. BREYER \& R. STEWART, supra note 99, at 377-97.

195. See G. VICKERS, FREEDOM IN A ROCKING BOAT 27, 50-54 (1970). 
This Article has also raised but not resolved several associated institutional questions. In our system, courts and litigation play an important role in the effort to maintain an evolutionary balance among different conceptions of social ends. But nothing in this essay warrants the conclusion that the courts' role in these tasks is paramount to that of other institutions of government, much less that courts have special license as guardians of any particular conception of regulation.

Some retail review of particular exercises of government power has seemed a prudential necessity at both the constitutional and subconstitutional levels. That necessity has arguably grown stronger with increases in the scale of administrative government. ${ }^{106}$

In the past, judicial adjudication has traditionally assumed major responsibility for aligning the exercise of public power in the United States with liberal principles. Enforcement of rights and correlative duties has been considered the courts' distinctive role. While the foundations of our administrative law still rest on private-law conceptions of rights, the expansion of regulation requires a reassessment of such traditions in the administrative context. As we have seen, the entitlement conception has only limited relevance to much regulatory administration. As we have also noted, courts lack strong institutional capabilities to identify and implement regulatory policies that will enhance wealth. Finally, it is not at all clear that courts possess a superior ability to sort out commodity and noncommodity values and ascertain their appropriate roles in regulatory programs.

These considerations suggest several different directions for regulatory and administrative law. Recognition of the limited relevance of entitlement conceptions and associated private law notions to contemporary regulation may help stimulate the evolution of a more truly public administrative law. At the same time, the importance of economic and policy competence may dictate that a substantial portion of the subconstitutional reviewing function could appropriately devolve onto non-judicial bodies. Internal executive branch review of regulatory measures is an example. The design of new, economic-based regulatory strategies to promote flexible, decentralized solutions and reduce the need for case-by-case review of particular commands can help lighten the strain on judicial competence and promote liberal values.

Answers to these questions of administrative policy and governance are the subject of lively debate. This Article has sought to make clear that successful answers must frankly acknowledge that regulation has impor-

196. But see J. MASHAW, supra note 3, at 202 (proposing elimination of judicial review of social security disability decisions). 
tant non-commodity objectives along with the protection of entitlements and the production of wealth. 